\title{
Polyphase Deformation of the High-Grade Metamorphic Rocks along the Neusspruit Shear Zone in the Kakamas Domain: Insights into the Processes during the Namaquan Orogeny at the Eastern Margin of the Namaqua Metamorphic Province, South Africa
}

\author{
Cyrille Stephane Tsakou Sonwa *(D), Jan van Bever Donker (D) and Russell Bailie (D)
}

Citation: Tsakou Sonwa, C.S.; van Bever Donker, J.; Bailie, R. Polyphase Deformation of the High-Grade Metamorphic Rocks along the Neusspruit Shear Zone in the Kakamas Domain: Insights into the Processes during the Namaquan Orogeny at the Eastern Margin of the Namaqua Metamorphic Province, South Africa. Minerals 2021, 11, 759. https://doi.org/10.3390/min11070759

Academic Editor: Tatsuki Tsujimori

Received: 13 April 2021

Accepted: 23 June 2021

Published: 14 July 2021

Publisher's Note: MDPI stays neutral with regard to jurisdictional claims in published maps and institutional affiliations.

Copyright: (c) 2021 by the authors. Licensee MDPI, Basel, Switzerland. This article is an open access article distributed under the terms and conditions of the Creative Commons Attribution (CC BY) license (https:/ / creativecommons.org/licenses/by/ $4.0 /)$.
Department of Earth Sciences, University of the Western Cape, Private Bag X17, Bellville, Cape Town 7535, South Africa; jvanbeverdonker@uwc.ac.za (J.v.B.D.); rbailie@uwc.ac.za (R.B.)

* Correspondence: stephanetsakou@gmail.com; Tel.: +27-21-959-2637
Abstract: The central part of the Namaqua Metamorphic Province was subjected to intense deformation under high-grade metamorphic conditions up to granulite facies, but also shows greenschist facies overprints denoting the metamorphic nature during the 1.2-1.0 Ga Namaquan Orogeny. This study examines the structural development of the central Kakamas Domain of the eastern Namaqua Metamorphic Province, which has not been extensively studied previously. The compressional orogenic phase is associated with $\mathrm{D}_{1}$ and $\mathrm{D}_{2}$ deformation events during which northeast-southwestdirected shortening resulted in southwest-directed thrusting illustrated by an intra-domain thrust and southwest-verging isoclinal folds. The post-tectonic Friersdale Charnockite of the Keimoes Suite is emplaced during the $\mathrm{D}_{3}$ deformation event. Late reactivation of the intra-domain thrust in the Kakamas Domain to form the Neusspruit Shear Zone during the $\mathrm{D}_{4}$ event is of a monoclinic nature and is described as a deeply rooted structure with shear direction towards the east. This structure, together with the more local Neusberg Thrust Fault, forms part of an intensely flattened narrow basin in the eastern Namaqua Metamorphic Province. Strain and vorticity indices suggest a transpressional shearing across the Neusspruit Shear Zone and adjacent regions probably initiated during the reactivation of the intra-domain thrust. The $\sim 1.2$ to $1.8 \mathrm{~km}$-wide, northwest-southeast striking dextral-dominated Neusspruit Shear Zone constitutes a western regional boundary for the supracrustal Korannaland Group and is composed of steep, narrow zones of relatively high strain, characterised by ductile deformation and penetrative strain.

Keywords: Kakamas Domain; Korannaland Group; pre- to syn-tectonic granitic gneisses; posttectonic charnockite; Namaqua Orogeny; Neusspruit Shear Zone; deformation

\section{Introduction}

The 1.3-1.0 Ga Namaqua-Natal Metamorphic Province of southern Africa is part of the global Grenvillian age orogenic belts [1-6]. It was involved in the formation of the Kalahari Craton [7] and was potentially associated with the assembly of the supercontinent Rodinia [8-10]. The Namaqua-Natal Metamorphic Province forms an arcuate belt stretching from the west coast of Namibia to the southeast coast of South Africa (e.g., [3,11-14] and references therein). It is divided into two sectors, namely the western Namaqua and eastern Natal sectors [13]. The Namaqua Metamorphic Province or Namaqua Sector (Figure 1) is of interest in this study and is subdivided into subprovinces. Regional stratigraphic and structural studies have, however, confirmed that the subprovinces host a number of tectonostratigraphic domains distinguished based on tectonic history, metamorphic grade and lithostratigraphic criteria, and separated by regional scale structural discontinuities. Although there is no consensus on the number of, or names for, these domains, summaries 
are given by $[5,11,13,15,16]$. In this paper, we follow the subdivisions and nomenclature of [13] and [16]. However, we prefer to use the non-genetic term "Domain" instead of "Terrane", as in [13], which is associated with a precise genetic definition related to accretionary tectonics (see [17]). The domain of interest in this study is the Kakamas Domain (Grünau Terrane of $[5,15]$ ), which is a prominent tectonic feature in the eastern Namaqua Sector (Figure 1). The Namaqua Sector is composed of severely deformed medium- to high-grade metamorphosed supracrustal and magmatic rocks and borders the western margin of the Archean Kaapvaal Craton in South Africa [3,6,13,18-22]. Various geological [1,6,11,15,23-28], geophysical [5,29-31], and geochronological [3,4,22,32-38] investigations suggest that the Namaqua-Natal Metamorphic Province was dominated by both compressional and extensional events during the 1.2-1.0 Ga Namaquan Orogeny (correlated with the Grenvillian).

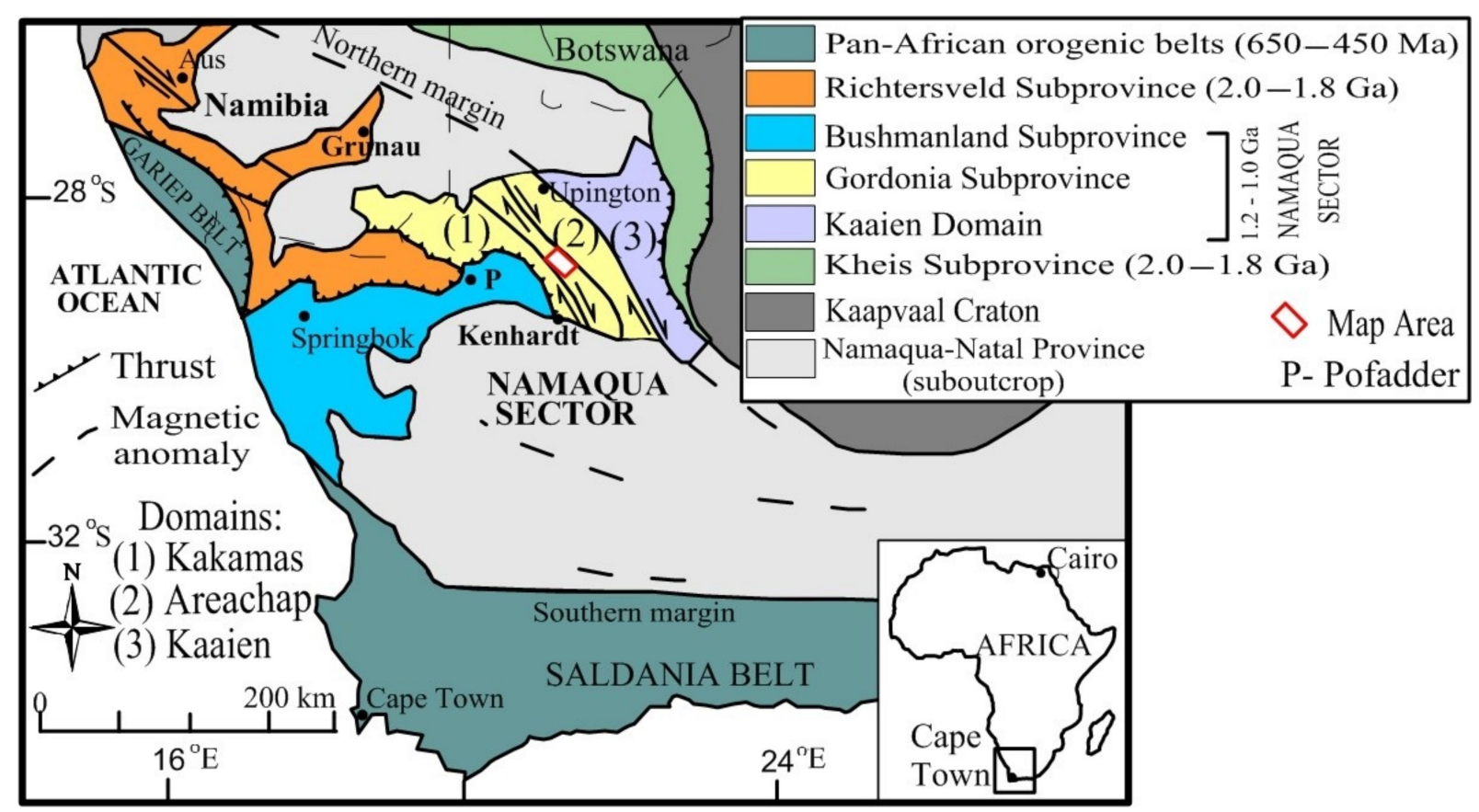

Figure 1. Geological subdivision of the Namaqua Sector of the Namaqua-Natal Metamorphic Province in South Africa (modified after [13]). The position of the study area is indicated. Abbreviations: P-Pofadder.

The stratigraphy and structure of the Kakamas Domain are loosely defined compared to other domains to the west [39,40] and those closer to the Archean Kaapvaal Craton in the east $[1,21]$. The Kakamas Domain has seen comparatively little research done compared to more recent work to the west in southern Namibia [3,38]. Despite the presence of volcanogenic massive sulphide (VMS) deposits in the adjacent Areachap Domain, there is little to no known mineralisation in the Kakamas Domain, apart from the presence of pegmatites [16]. An early investigation in the Kakamas Domain by [41] focused on phacoliths of charnockitic monzogranite-porphyry of an area around Keimoes, which was later classified as the Friersdale Charnockite of the Keimoes Suite [16,22,37], and references therein. Another study [25], however, focused on the structural and metamorphic evolution of an area around Kakamas and Keimoes. More recently, Reference [6] investigated the structure and stratigraphy of an area near Kakamas. In addition, there have been several recent detailed geochemical and geochronological studies with regards to the Mesoproterozoic crustal evolution and emplacement ages of various syn- and/or post-tectonic intrusions in the Kakamas Domain $[4,22,37,38,42,43]$. There has, however, been little recent work done on the structural evolution of the Kakamas Domain.

In light of the investigations associated with the Kakamas Domain, this study concentrates on the understanding of the processes taking place at high-grade metamorphic 
conditions during the Namaqua Orogeny in an area east of the Neusspruit Shear Zone and south of the Orange River (Figure 2). As the Neusspruit Shear Zone is a prominent intra-terrane shear zone within the Kakamas Domain, this paper contributes to the understanding of the structural-metamorphic development around such structures in the eastern Namaqua Sector.

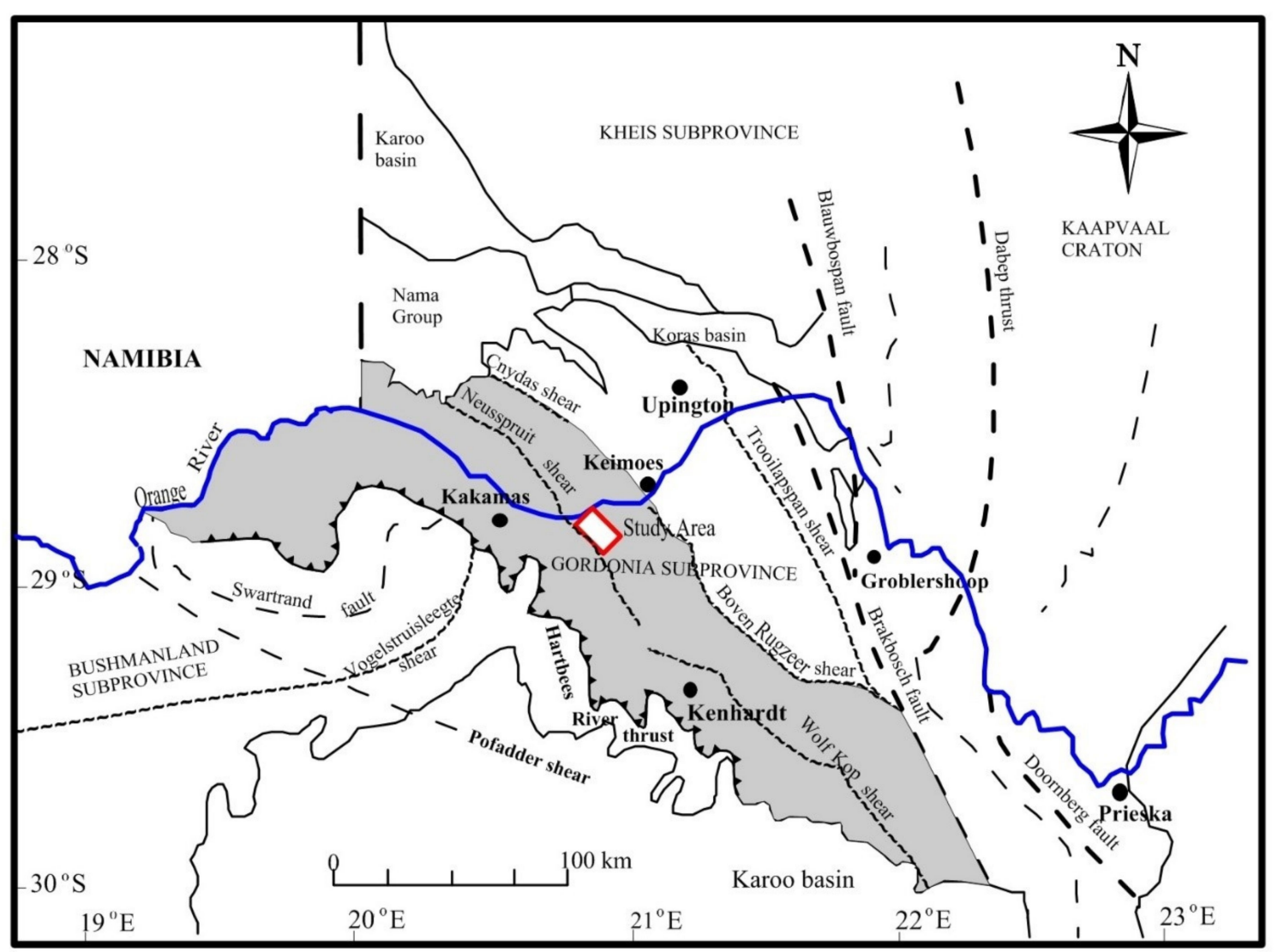

Figure 2. General distribution of major tectonic structures in the Namaqua Sector displaying Table 44.

\section{Geological Setting}

The Namaqua Metamorphic Province is subdivided into various subprovinces (Figures 1 and 2), defined by distinctive stratigraphic units bounded by structural discontinuities. The domains and subprovinces were variably deformed and metamorphosed during the 1.2-1.0 Ga Namaqua Orogeny. Although the precise geometry remains controversial, there is evidence that the rocks of the Gordonia Subprovince (comprising the Kakamas and Areachap domains-Figure 1) are stratigraphically and structurally distinct from those of the Bushmanland Subprovince to the west [24]. The Gordonia Subprovince is separated from the Kheis Terrane at its eastern boundary by the Brakbosch Fault east of $22^{\circ} \mathrm{E}$ and along the Trooilapspan Shear Zone west of $22^{\circ} \mathrm{E}$ (Figure 2). The western boundary is along the Hartbees River Thrust Zone east of $20^{\circ} \mathrm{E}$ and along the Swartrand Fault west of $20^{\circ} \mathrm{E}[16,44]$ (Figure 2). The southern portion of the Gordonia Subprovince extends to the Kenhardt region, where it disappears beneath younger Palaeozoic cover rocks [13]. The Gordonia Subprovince is transected by Mesoproterozoic faults and shear zones trending mostly northwest-southeast (Figure 2), some of which are major structures of regional importance $[1,5,6,13,16,25]$.

A close relationship between metamorphism and deformation is demonstrated in the Namaqua Sector, which is subjected to different types of tectonics [5]. In the west and south of the Namaqua Sector, metamorphic studies revealed anti-clockwise $P-T$-t paths [45] interpreted as convective heat transfer by crustal melting and intrusive magma, which 
thickened the crust [45,46], without crustal stacking [5]. Another study [47], however, proposed that anti-clockwise $P$ - $T$-t paths are related to advective heat flow combined with intrusive magmatism during compression rather than extension. The central, eastern, and northern parts of the Namaqua Sector, by contrast, show clockwise $P$ - $T$-t paths as a result of tectonic stacking, associated with advective heat transfer related to voluminous intrusive magma. This is reflected in the granulite facies conditions experienced by the Kakamas Domain, although the tectonic processes are linked to crustal extension [38,48,49].

The Kakamas Domain was first investigated by [50] when they published their memoir on the geology of an area around Kakamas. The Kakamas Domain consists of severely reworked Mesoproterozoic magmatic and supracrustal rocks [16,24,25,38], and was subjected to various tectonic events, including voluminous magmatic emplacement, thrusting, shearing, thickening, and uplift of the crustal sequence, due to a consistent stress regime with a general movement towards the Kaapvaal Craton $[13,20,27]$. Investigations to the west in the Bushmanland Subprovince $[39,40,51-54]$, and to the east in the Areachap Domain (Figure 1) [55-57] have established the occurrence of base metal mineralization, which is not yet identified in the Kakamas Domain.

The Kakamas Domain was subjected to a polyphasic metamorphism comprising four distinguishable events. The first event $\left(\mathrm{M}_{1}\right)$ occurred at 1220-1180 Ma [48] and reached granulite facies conditions of high- $T$, low- $P$ metamorphism with temperatures between 800 and $900{ }^{\circ} \mathrm{C}$, and pressure of about $5 \mathrm{kbar}$ [48]. Similar conditions were established in the Aggeneys Domain [58]. This event is related to the emplacement of various S- and A-type granitoids associated with anatexis in the metapelites [38,48].

The second metamorphic event $\left(\mathrm{M}_{2}\right)$ occurred between 1200 and $1100 \mathrm{Ma}[38,48]$ and is associated with isobaric heating conditions $[48,59]$ related to the emplacement of syn-tectonic granitoids [38,48]. Subsequently, the region was intruded by voluminous, post-tectonic granitoids of the Keimoes Suite of 1113-1080 Ma age, e.g., [22,37,38]. The intrusion of granitic rocks and granitic dykes occurred at conditions of $T=640-550{ }^{\circ} \mathrm{C}$ and $P=4.8 \mathrm{kbar}[42,59]$. Reference [22] interpreted the high- $T$ metamorphism to represent post-collisional thermal equilibration and likely extension and thinning of the crust.

The $\mathrm{M}_{3}$ metamorphic event occurred at $T=\sim 350{ }^{\circ} \mathrm{C}$ and $P=\sim 2.5 \mathrm{kbar}$ conditions [25], and has been interpreted as a retrogressive event, producing greenschist facies conditions, marked by the presence of secondary minerals such as muscovite, epidote, and chlorite in the supracrustal rocks [16,25]. It is therefore concluded that the geochronologic evidence points to the episodic nature of metamorphic events in the Kakamas Domain.

The Neusberg Mountain (Figure 3) is underlain by highly deformed magmatic rocks metamorphosed to amphibolite to granulite facies conditions, along with calc-silicates, and feldspathic quartzites of the Korannaland Group $[16,25,41,50]$. This supracrustal succession is restricted to the Gordonia Subprovince and comprises metamorphosed sedimentary rocks [16] (Figure 3). The Neusberg Mountain occurs as a highly deformed northwesttrending belt, intruded by various granitoids. The area under discussion (Figures 2 and 3 ) has been described as a high- $T$, low- $P$ type of metamorphic environment [25], where conditions decrease from granulite facies at its western boundary along the Hartbees River Thrust ( $T=650-750{ }^{\circ} \mathrm{C} ; P=5 \mathrm{kbar}$ ) [60], to lower amphibolite facies in the east near Keimoes ( $T=\sim 550^{\circ} \mathrm{C} ; P=\sim 2 \mathrm{kbar}$ ) [61]. In addition, evidence of retrograde greenschist facies overprinting has been reported $[16,25,60]$. Petrographic and metamorphic investigations by [25,61], amongst others, emphasize the polyphase metamorphic nature of the Kakamas Domain. 


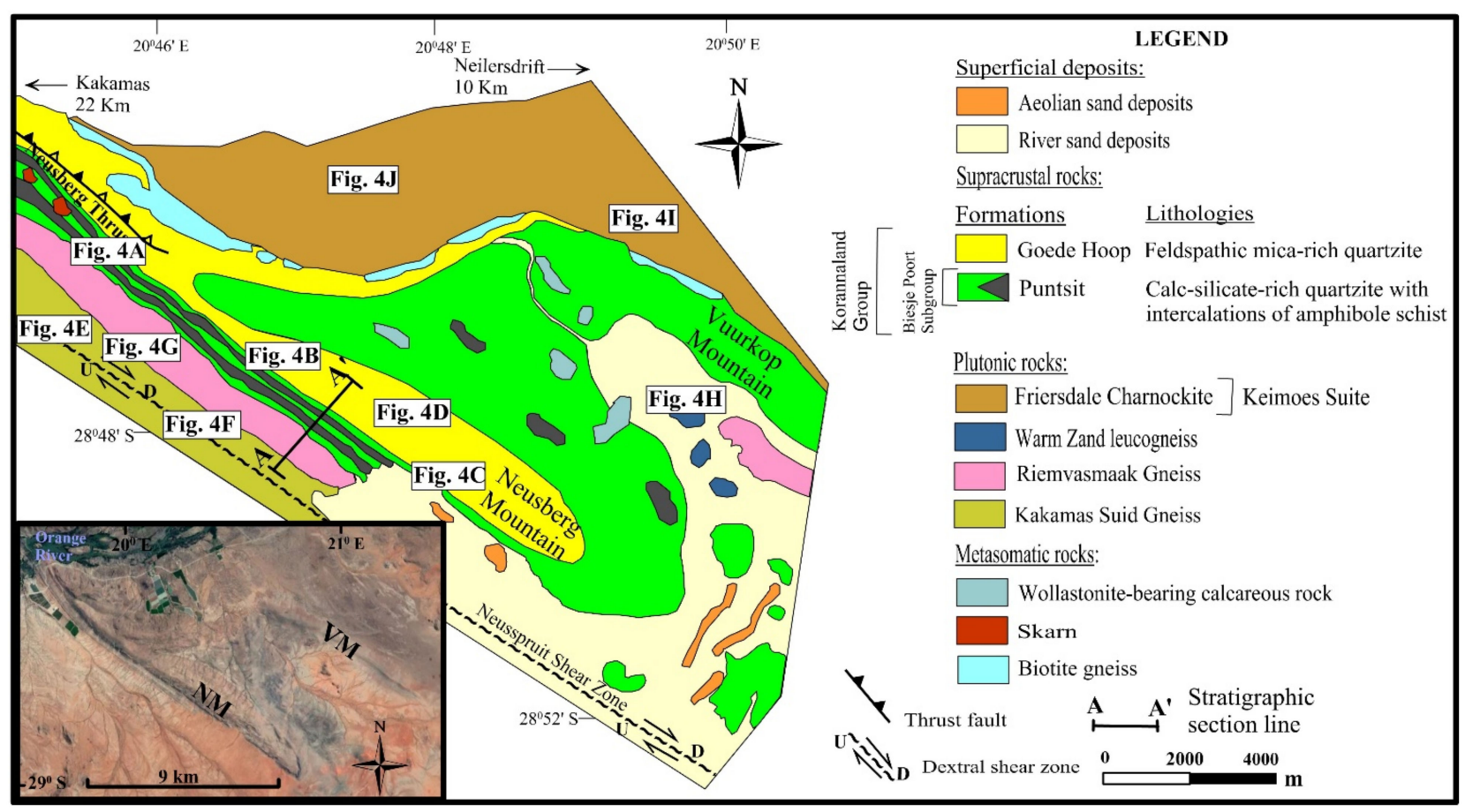

Figure 3. Geological map of the Neusberg Mountain showing the location of various rock types within the study area and its position within the Kakamas Domain of the Namaqua Sector, South Africa. Inset of the satellite image displaying the entire extent of the Neusberg Mountain in the study area.

The Kakamas Domain underwent various deformation events. Previous investigations have identified four main deformation events in the Kakamas Domain during the 1.2-1.0 Ga Namaqua Orogeny, e.g., $[6,16,25,26]$; the correlation of these events on a regional scale remains, however, problematic. The early deformation event, $\mathrm{D}_{1}$, is recorded as compressional deformation at $1197 \pm 5$ Ma based on detrital zircon ages, supported by metamorphic ages at $1194 \pm 23 \mathrm{Ma}$ [20]. The planar fabric $\left(\mathrm{S}_{1}\right)$ in the pre-tectonic plutons (the Kakamas Suid Gneiss, Riemvasmaak Gneiss and Warm Zand leucogneiss) is defined by a foliation that is co-planar to the lithological banding and is attributed to large-scale transposition during $\mathrm{D}_{1}[6,27,62]$. The $\mathrm{D}_{2}$ deformation event has been reported as the main folding phase and is expressed by the formation of tight to isoclinal subvertical northwest-trending $\mathrm{F}_{2}$ folds and a regional axial planar fabric $\left(\mathrm{S}_{2}\right)$, which is parallel to the transposed $S_{0} / S_{1}$ banding $[6,16,25,63]$. The $D_{2}$ deformation event is constrained to have occurred between $\sim 1155 \mathrm{Ma}$ and $1100 \mathrm{Ma}$ as it has been associated with syn-tectonic granite intrusions $[38,42]$. The subsequent $\mathrm{D}_{3}$ deformation event is characterised by open east-west-trending $\mathrm{F}_{3}$ folds and is associated with post-tectonic magmatism [35,42], illustrated by the emplacement of the Friersdale Charnockite at $1080 \pm 13$ Ma [43]. The $\mathrm{D}_{4}$ deformation event is related to dextral strike-slip faulting along major regional shear zones and faults, e.g., [37,56], between 1040 and $1020 \mathrm{Ma}[48,64]$.

\section{Methodology}

A two-pronged approach, addressing both the lithostratigraphy and structural analyses, was undertaken in this study. Sampling localities were selected based on accessibility and exposure in the field (Figure 3). The outcrops of the supracrustal and plutonic rocks were described on the basis of field occurrence and hand specimen, as well as petrographically. Samples of the various gneisses and post-tectonic pluton were collected from relatively fresh homogenous outcrops in the study area (Figure 3) for thin-section petrographic and microstructural analysis using a Zeiss petrographic microscope and an Olympus X-43 digital camera. Shear sense indicators in the Kakamas Suid Gneiss were assessed by cutting thin sections perpendicular to the foliation (Figure 4F). 
Published geological and structural maps were also used for examination and interpretation of geological features. Mapping was based on topographic and previously published geological maps, aerial-photographs, and digital aerial photos to develop a visual understanding and representation of the study area. The 1:250,000 scale 2820 Upington geological map [65] is used for the regional geology. The published 1:50,000 topographic map (2820 DD Koekoeb) from the Department of Mapping and Survey was used as the base map for the study area, where the geology was interpolated. The orthophoto-map series, at a scale of 1:10,000, combined with the aerial photographs and digital aerial photos, were used to interpret the geology and structures.

The structure observed in the study area consists of a macrofold stretching from the Neusberg (NM) to Vuurkop (VM) Mountains, respectively (Figure 3). Rather than analysing the heterogeneously deformed macroscopic structure in the study area in one section, it is best understood by dividing the entire structure into three sub-areas where the individual structure can be described as homogeneously deformed (Figure 3). Various strain features, such as fold axes, axial planes, and foliations, along with shear sense indicators, such as vorticity indicators, were observed and recorded. The fold axes were derived by plotting the poles using a $\pi$-diagram, and to do this accurately, we include the poles to planes around each hinge and not just the limbs of the fold. Their orientations were plotted stereographically using the software package Stereonet version 10.0 [66]. The orientations of the fold axis and main foliation plane were determined for each sub-area. The structure in each sub-area is classified based on the attributes of the fold axis and main foliation plane as described by [67]. Various geological and structural maps were compiled using the software packages Surfer version 16 and ArcMap version 10.3.1. Supplementary analytical datasets are given in the Table S1.

\section{Results}

\subsection{Lithostratigraphy}

The stratigraphy of the area under consideration consists of supracrustal and plutonic rocks. In this study, detailed mapping revealed a complex distribution of the rocks, which are loosely characterised geochemically and ill-defined geochronologically in the literature. The stratigraphic nomenclature used in this study relates to that of $[16,22,25,41,44,65,68]$. The recognition of primary sedimentary structures can be a useful tool in the interpretation of severely deformed and metamorphosed rocks. Sedimentary features, such as bedding, gradation, lamination, trough cross-bedding, and the presence of pebbles are, therefore, important features to distinguish between different lithologies in the supracrustal succession and give an idea as to potential protoliths with the view to unravelling the depositional environment. The magmatic rocks were identified and differentiated by means of criteria such as the presence of augen, texture, mineralogy, and the presence of felsic and/or mafic xenoliths. The lithostratigraphy from both the supracrustal and plutonic rocks in the study area are described from the youngest to the oldest lithology based on available ages and field relationships (Table 1). The contact rocks are also described.

\subsubsection{Supracrustal Rocks}

The supracrustal rocks making up the Neusberg Mountain (NM) are the Puntsit Formation of the Biesie Poort Subgroup overlain by the Goede Hoop Formation of the Korannaland Group (Table 1). These formations are part of the stratigraphic profile in Figure 4. The Biesie Poort Subgroup is made up of various formations as summarised by [16]. The Puntsit is the only formation of the Biesie Poort Subgroup identified in the study area. 


\section{Puntsit Formation}

The Puntsit Formation has the widest distribution and is traced to the southern closure of the NM (Figure 3). It builds the topmost succession of the Vuurkop Mountain (VM), where it underlies a rocky ridge due to the presence of wollastonite-bearing calcareous rock. Wollastonite-bearing calcareous rocks occur sporadically between the Neusberg and Vuurkop (Figure 3) as lenses of about $1.5 \mathrm{~m}$ length, and approximately 10 to $40 \mathrm{~cm}$ width. The wollastonite-bearing calcareous rock has an inequigranular texture and displays a flat-lying flow banding-like structure. They are white to greyish in colour with lath-shaped grains of 2-5 mm in length. Skarn occurs as small, brown to dark brown fine-grained patches within the formation to the west of the Neusberg (Figure 3). Where fresh, the skarn contains lenses of quartzite and patches of epidote.

The calc-silicate-rich quartzites are fine- to medium-grained and show a parting at irregularly spaced intervals parallel to the bedding. Primary sedimentary structures, such as bedding planes, are observed and are similar to those in the overlying feldspathic mica-rich quartzite. No crossbedding has been identified in the Puntsit Formation in the area under consideration. There is a sharp contact between the Puntsit Formation and the overlying Goede Hoop Formation. The contacts between the calc-silicate-rich quartzite and the intercalated amphibole schist (Figure 4A) are commonly gradational. The amphibole schist is fine-grained, brown in colour, with bands varying in thickness from a few millimetres to about $10 \mathrm{~cm}$. The prominent northwest-southeast trending foliation is concordant with the regional northwest-southeast structural trend in the calc-silicaterich quartzites.

\section{Goede Hoop Formation}

The Goede Hoop Formation comprises feldspathic mica-rich quartzite as defined by $[16,68]$. It exhibits a granoblastic texture and underlies prominent ridges to the east of the Neusspruit Shear Zone (Figure 3). It is the youngest and uppermost formation of the Korannaland Group. Primary sedimentary structures, such as crossbedding (Figure 4B), the presence of pebbles (Figure 4C), and graded bedding (Figure 4D) are locally preserved. Cross-bedded structures show a younging direction to the northeast defined by upwards fining cycles (Figure 4D). The feldspathic mica-rich quartzite is medium- to coarse-grained, and, in a similar fashion to the calc-silicate-rich quartzite, also shows a parting at variously spaced intervals parallel to the foliation. The intrusive contact with the Friersdale Charnockite is characterised by a contact zone comprising biotite gneiss, which is mapped for a total length of about $200 \mathrm{~m}$ (Figure 3). The biotite gneiss is medium- to coarse-grained and contains lenses of mafic composition of about 4 to $7 \mathrm{~cm}$ in size.

\subsubsection{Plutonic Rocks}

The plutonic rocks crop out as hills or large continuous rocks in the study area. The absolute age relations of the plutonic rocks in the area under consideration are unclear at present so that careful assessment of contact relationships is, therefore, required. The plutonic rocks are represented by the Kakamas Suid Gneiss, the $1156 \pm 8 \mathrm{Ma}$ to $1151 \pm 14 \mathrm{Ma}$ Riemvasmaak Gneiss ([43]; which correlates to the $1155 \pm 7$ Ma Rooipad Granite of [4]), the Warm Zand leucogneiss, and the $1080 \pm 13$ Ma Friersdale Charnockite of the Keimoes Suite [22] (Figure 3). In this paper, the term used for continuity purposes will be Riemvasmaak Gneiss, after [16]. 

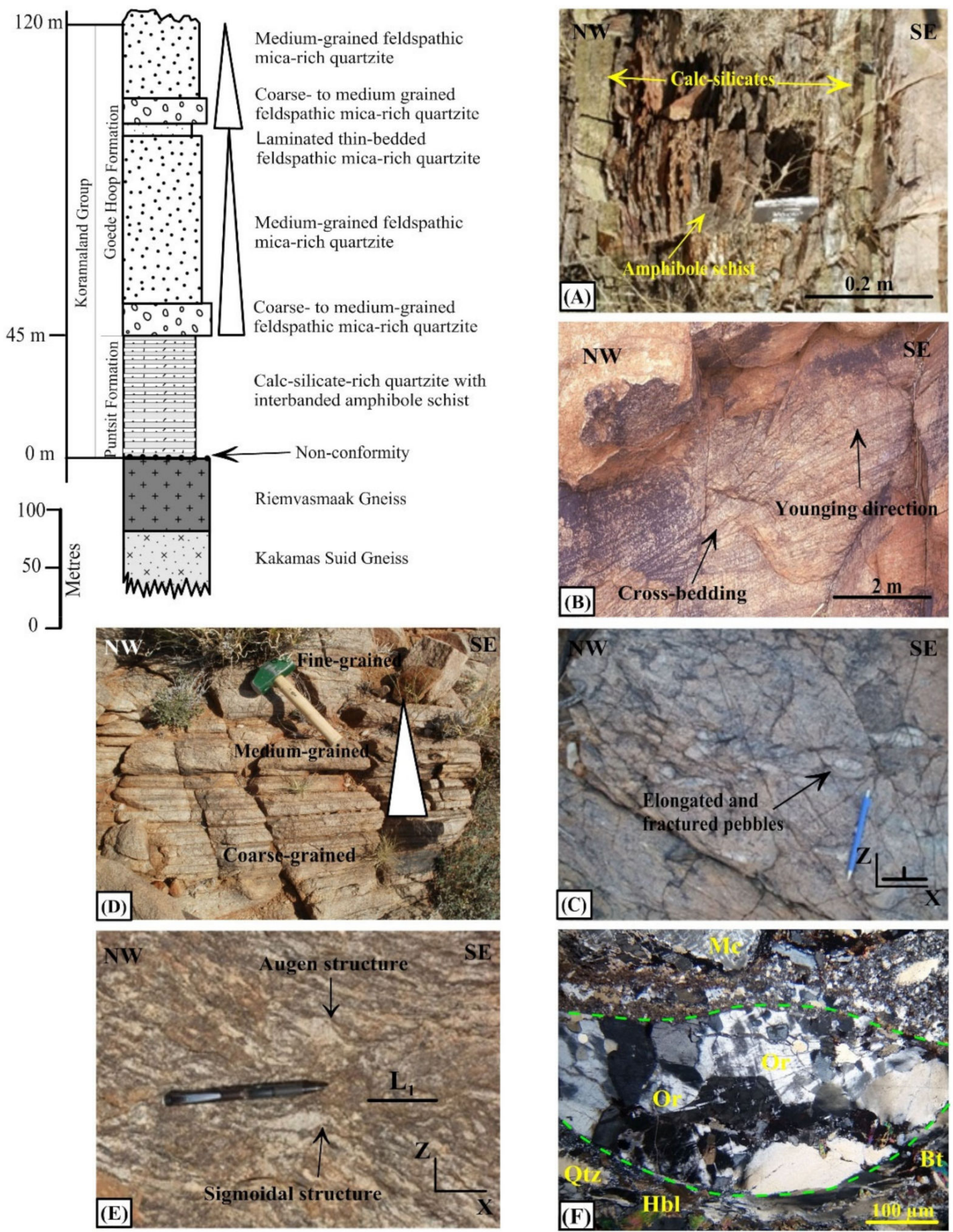

Figure 4. Cont. 

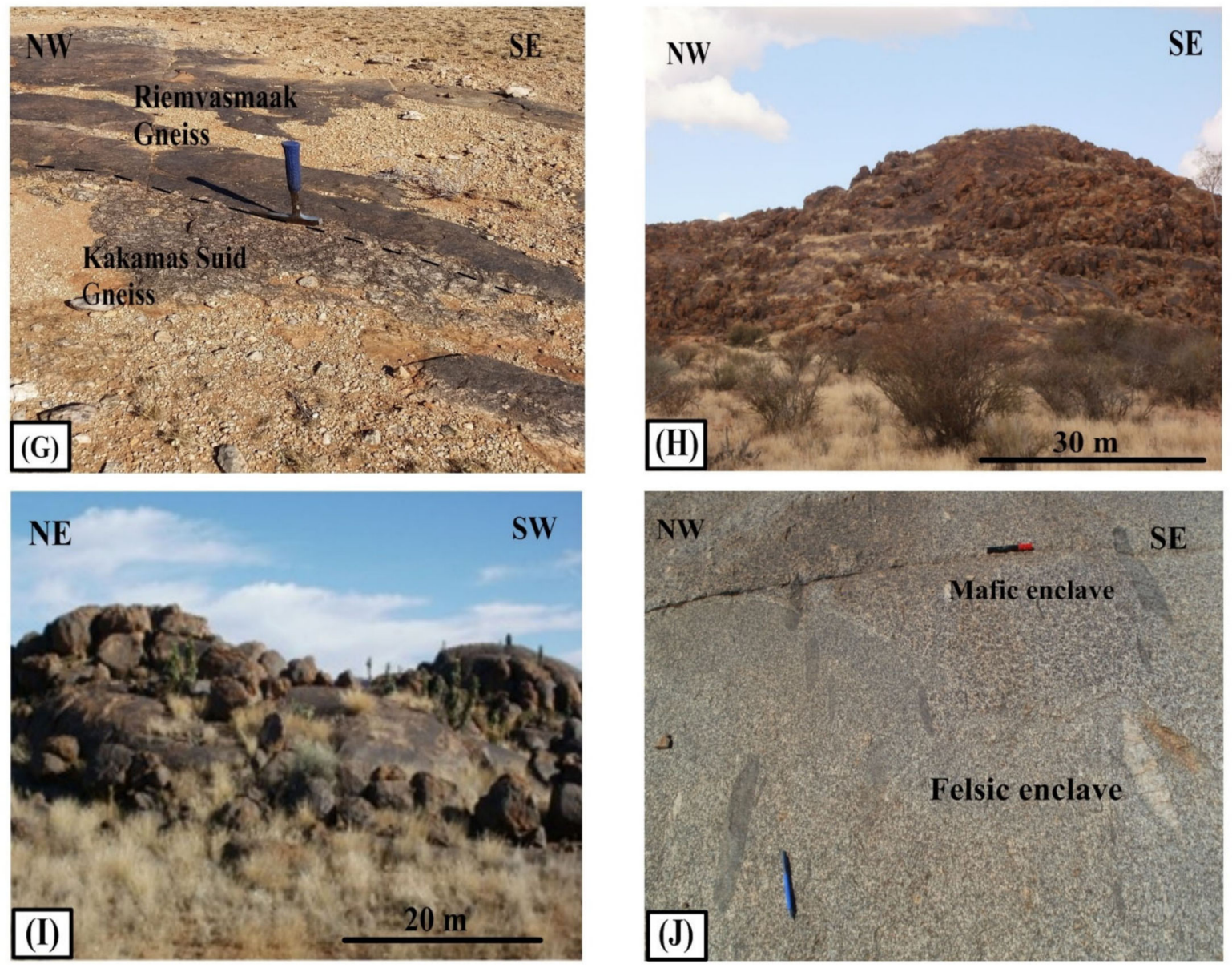

Figure 4. Stratigraphic profile along the representative section line A-A' west of the Neusberg Mountain. The location of the section is given in Figure 3. (A) Intercalated layers of calc-silicate-rich quartzite with brown amphibole schist exhibiting well-preserved northeast-dipping $S_{0}$ foliation parallel to $S_{1}$ in metasediments of the Puntsit Formation in the Neusberg Mountain (white line is the edge of the notebook). (B) Crossbedding observed in the feldspathic mica-rich quartzite of the Goede Hoop Formation and defined by the compositional banding $\left(\mathrm{S}_{0}\right)$. The younging direction is top normal towards the northeast. (C) Outcrop of feldspathic mica-rich quartzite dipping northeast, showing the XZ-plane of the strain ellipsoid defined by the elongated pebbles in the outcrop surface. (D) Upward fining cycle in the feldspathic mica-rich quartzite of the Goede Hoop Formation. (E) Outcrop of the Kakamas Suid Gneiss displaying an augen structure. The fabric is defined by elongate quartzo-feldspathic sigmoidal-like structures. The XZ-plane of the strain ellipsoid is defined by the elongated aggregates of quartz-feldspar in the outcrop surface. (F) Photomicrograph of the Kakamas Suid Gneiss showing well-delineated quartz-feldspar augen. Abbreviations: Qtz = Quartz; Or = Orthoclase; Mc = Microcline; $\mathrm{Hbl}=$ Hornblende; $\mathrm{Bt}=$ Biotite. $(\mathbf{G})$ Sharp contact between the Riemvasmaak Gneiss and the Kakamas Suid Gneiss. The contact is demarcated by a black dotted line. (H) Panoramic view of the distribution of the Warm Zand leucogneiss as small and separated hills, looking to the southeast between the Neusberg and Vuurkop Mountains. (I) Exfoliated rocks of the Friersdale Charnockite, looking to the northeast along the contact zone. (J) Medium-grained granoblastic texture of the Friersdale Charnockite with enclaves of mafic and felsic composition. 
Table 1. Subdivision of the lithostratigraphic units of the South Central Zone in the Kakamas Domain, eastern Namaqua Sector. Summary after $[16,22,25,41,44,68]$.

\begin{tabular}{|c|c|c|c|c|c|c|c|c|}
\hline Group & Subgroup & Suite & $\begin{array}{c}\text { Formation/ } \\
\text { Nature }\end{array}$ & Member/ Unit & Rock Type & Age (Ma) & Thickness (m) & Description \\
\hline & & Keimoes & & $\begin{array}{l}\text { Friersdale } \\
\text { Charnockite }\end{array}$ & Intrusive rock & $1113-1080$ & & $\begin{array}{c}\text { Opalescent blue } \\
\text { quartz, lenses of felsic } \\
\text { and mafic } \\
\text { composition, } \\
\text { medium- to } \\
\text { coarse-grained, } \\
\text { granoblastic texture }\end{array}$ \\
\hline \multicolumn{9}{|c|}{ Non-conformity } \\
\hline \multirow[t]{2}{*}{ Korannaland } & & & $\begin{array}{l}\text { Goede Hoop } \\
\text { (Fluviatile) }\end{array}$ & $\begin{array}{l}\text { Feldspathic } \\
\text { mica-rich } \\
\text { quartzite }\end{array}$ & \multirow{2}{*}{$\begin{array}{l}\text { Supracrustal } \\
\text { rock }\end{array}$} & & $140-200$ & $\begin{array}{c}\text { Medium to } \\
\text { coarse-grained } \\
\text { quartzite, } \\
\text { granoblastic texture, } \\
\text { well-bedded, } \\
\text { presence of pebbles, } \\
\text { extensively intruded } \\
\text { by Friersdale } \\
\text { Charnockite, biotite } \\
\text { gneiss within the } \\
\text { contact zone }\end{array}$ \\
\hline & Biesie Poort & & $\begin{array}{c}\text { Puntsit } \\
\text { (psammitic } \\
\text { and calcareous } \\
\text { with } \\
\text { intercalations } \\
\text { of likely } \\
\text { basaltic } \\
\text { material) }\end{array}$ & $\begin{array}{c}\text { Calc-silicate- } \\
\text { rich quartzite } \\
\text { with } \\
\text { intercalations } \\
\text { of amphibole } \\
\text { schist }\end{array}$ & & & $30-80$ & $\begin{array}{c}\text { Fine- to } \\
\text { medium-grained } \\
\text { quartzite, } \\
\text { granoblastic texture, } \\
\text { presence of } \\
\text { intercalations of } \\
\text { fine-grained } \\
\text { amphibole schist, } \\
\text { well-bedded, lenses } \\
\text { of skarn and } \\
\text { wollastonite-bearing } \\
\text { calcareous rock }\end{array}$ \\
\hline \multicolumn{9}{|c|}{ Non-conformity } \\
\hline & & & & $\begin{array}{l}\text { Warm Zand } \\
\text { leucogneiss }\end{array}$ & \multirow{3}{*}{ Intrusive rock } & & & $\begin{array}{l}\text { Brown in colour, fine- } \\
\text { to medium-grained, } \\
\text { quartz and feldspar, } \\
\text { faint streaks of } \\
\text { amphibole and } \\
\text { biotite, granoblastic } \\
\text { texture }\end{array}$ \\
\hline & & & & $\begin{array}{c}\text { Riemvasmaak } \\
\text { Gneiss }\end{array}$ & & & & $\begin{array}{c}\text { Pink in colour, } \\
\text { medium- to } \\
\text { coarse-grained, } \\
\text { quartz and feldspar, } \\
\text { amphibole and } \\
\text { biotite, granoblastic } \\
\text { texture }\end{array}$ \\
\hline & & & & $\begin{array}{c}\text { Kakamas Suid } \\
\text { Gneiss }\end{array}$ & & & & $\begin{array}{l}\text { Grey to brown in } \\
\text { colour, augen texture, } \\
\text { feldspar mylonites, } \\
\text { inequigranular } \\
\text { showing augen } \\
\text { texture }\end{array}$ \\
\hline
\end{tabular}

\section{Basement}

The basement on which the supracrustal rocks of the various domains were deposited is one of the enigmas in the Namaqua Sector. It was demonstrated that the basement could be anything in the range of $1.8-2.0 \mathrm{Ga}$ in age $[3,13,33,38,48,69]$. In the study area, the supracrustal rocks are represented by the Korannaland Group.

It was established that the enigmatic basement for the supracrustal rocks of the Namaqua Sector is early to middle Orange River Orogeny crust of $\sim 1.7$ Ga age [5]. The Orange River Orogeny basement stretches from the Kaapvaal Craton westwards underneath the Kakamas Domain and the Bushmanland Subprovince and appears as migmatitic rocks of low-P granulite facies in the western Bushmanland Subprovince, e.g., [3,5]. Isotopic studies on the migmatites and crustal xenoliths in the western Bushmanland Subprovince yielded ages of 1.9-1.7 Ga [70,71] confirming an elusive Paleoproterozoic-aged basement in the Namaqua Sector $[5,72]$. 


\section{Kakamas Suid Gneiss}

The Kakamas Suid Gneiss is present west of the Neusberg Mountain (Figure 3). This lithology has not received much attention in the literature. A previous study [25] added it with their Wolfkop Formation, while [41] described the Kakamas Suid Gneiss as grey gneiss, based on its slightly elevated biotite content [16]. It displays a brown weathered colour (Figure 4E) and is grey when fresh. It consists of quartz, orthoclase, biotite, hornblende, microcline, and plagioclase. It is well-foliated, medium- to coarse-grained, and exhibits an inequigranular fabric displaying an augen texture. It contains flattened and stretched quartz-feldspar aggregates of 2 to $4 \mathrm{~cm}$ in size, which define augen structures (Figure $4 \mathrm{E}$ ). The foliation is defined by the alignment of mafic minerals and the intermediate axis of the augen. The long axes of the augen lie within the foliation plane. Strong anastomosing foliation is well-defined (Figure $4 \mathrm{~F}$ ). The presence of K-feldspar-dominated augen suggests an intrusive origin.

\section{Riemvasmaak Gneiss}

The Riemvasmaak Gneiss/Rooipad Granite ([16] and [4], respectively) is identified by [16] as a variety of pink gneiss. The sharp contact with the Kakamas Suid Gneiss (Figure 4G), the presence of xenoliths, and lit-par-lit contact relationships [6,16] suggest an intrusive origin. The pinkish Riemvasmaak Gneiss is medium- to coarse-grained, with a granoblastic texture, foliated, and contains alkali feldspar, quartz, biotite, hornblende, and plagioclase. Xenoliths with lenticular shape consist of fine-grained quartz, alkali feldspar, and biotite. The contacts with the surrounding gneisses are sharp and obscured in some places by Quaternary sand deposits. The contact with the calc-silicate-rich quartzite of the Puntsit Formation is sharp, which suggests it is younger than, and intrusive into, the supracrustal rocks. This then constrains the age of deposition of the Korannaland Group. An age of emplacement of $1151 \pm 14 \mathrm{Ma}$ was reported for the Riemvasmaak Gneiss [43], with the synonymous Rooipad Granite having an emplacement age of $1155 \pm 7$ Ma [4,6] further north of the study area in the Kakamas Domain.

\section{Warm Zand Leucogneiss}

The Warm Zand leucogneiss outcrops as a hill of exfoliated boulders (Figure 4H) between the Neusberg and Vuurkop (Figure 3). A similar lithology was also identified in the Areachap Domain [72]. It has a brown weathered colour and is pink when fresh. It is fineto medium-grained, displays a granoblastic texture, and contains alkali feldspar, quartz, hornblende, and biotite in decreasing abundance. Foliation is faintly visible compared to the Kakamas Suid Gneiss due to this gneiss having a lower content of mafic minerals such as hornblende, biotite, and opaques. No mafic or felsic enclaves have been identified in the leucogneiss. The contacts with the other plutonic rocks and the supracrustal succession are covered by Quaternary sand deposits.

\section{Friersdale Charnockite}

The Friersdale Charnockite occurs as exfoliated boulders (Figure 4I), and large and continuous outcrops in the northern, north-eastern, and eastern parts of the study area (Figure 3). It intrudes the Puntsit and Goede Hoop Formations of the Korannaland Group in the study area. The weathered Friersdale Charnockite shows onion skin exfoliation. This lithology exhibits a grey to brown colour, is weakly foliated, and is medium- to coarsegrained displaying a granoblastic texture. It contains alkali feldspar, blue opalescent quartz, and biotite, along with lenses of felsic or mafic composition of about 3 to $10 \mathrm{~cm}$ in size (Figure 4J). There is a sharp contact between the supracrustal rocks and the Friersdale Charnockite in the study area. In some places, the contact is delineated by a foliated biotite gneiss observed nowhere else in the area under consideration. The biotite gneiss has a granoblastic texture, which can be interpreted as a contact metamorphic effect. Mafic lenses in the biotite gneiss also occur in the Friersdale Charnockite but are not found in the supracrustal rocks. The foliation in the biotite gneiss and in the feldspathic mica-rich 
quartzite of the Goede Hoop Formation are concordant. The Friersdale Charnockite is emplaced at $1080 \pm 13 \mathrm{Ma}$ and classified as a late- to post-tectonic granite in the Kakamas Domain [22]. The presence of the Friersdale Charnockite as large and continuous outcrops and containing lenses of mafic and felsic composition suggest an intrusive origin.

\subsection{Metamorphism}

The metamorphic activity in the Kakamas Domain is a classic high- $T$ and low- $P$ type in the Namaqua Sector. The $\mathrm{M}_{1}$ metamorphism is of granulite facies estimated at $T=800-900{ }^{\circ} \mathrm{C}$ and $P=\sim 5 \mathrm{kbar}$ and occurred at 1220-1180 Ma [48]. Similar conditions were determined in the Riemvasmaak area [68] and also in the Central dome near Kakamas [25]. The $\mathrm{M}_{2}$ metamorphic event occurred under slow cooling and heating episodes at near constant mid-crustal pressure conditions [48,59], associated with the emplacement of syn-tectonic granitoids between 1200 and 1150 Ma [38] in the Kakamas Domain [16]. The subsequent $\mathrm{M}_{3}$ event occurred during the emplacement of voluminous post-tectonic granitoids of the Keimoes Suite between 1113-1080 Ma, e.g., [22,37,38] with estimated P-T conditions of $T=640-550{ }^{\circ} \mathrm{C}$ and $P=4.8 \mathrm{kbar}[21,42,58]$ in the Kakamas Domain. The low-grade $\mathrm{M}_{4}$ metamorphic event is expressed by the late growth of minerals such as epidote and muscovite, which occurred adjacent to the Neusspruit Shear Zone. Late-grown biotite at the expense of garnet was also identified by [25]. The metamorphic conditions were estimated at $T=\sim 350^{\circ} \mathrm{C}$ and $P=\sim 2.5 \mathrm{kbar}[25]$.

\subsection{Structure}

\subsubsection{Neusberg Macrofold}

The regions on the map marked as various sub-areas enclose the essential structural feature of that sub-area (Figure 5). Each sub-area highlights a reasonable continuity of individual structure to distinguish the various stages of deformation that took place. Observations and related interpretations of structural patterns within each sub-area are compared and correlated in order to produce a common and comprehensive deformational history for the entire structure in the study area.

\subsubsection{Structural Fabrics and Related Metamorphic Grade}

Pervasive foliation was developed in the intrusive rocks and most of the supracrustal rocks. The planar fabric in the pre-tectonic plutons $\left(\mathrm{S}_{1}\right)$ is defined by a compositional banding, which is co-planar to the lithological foliation. The $S_{1}$ foliation is mainly defined by the transposition of the primary bedding $\left(\mathrm{S}_{0}\right)$ forming early $\mathrm{F}_{1}$ isoclinal folding, which may be a tectonically produced surface $\left(S_{1}\right)[6,25,62]$. The $S_{1}$ foliation is identified as a shearrelated fabric in the supracrustal and intrusive rocks, and co-planar to the XY-plane of the strain ellipsoid, e.g., $[73,74]$. The L-fabric $\left(\mathrm{L}_{2}\right)$ is defined by elongated pebbles, sigmoidal quartz-feldspar grains, and mineral lineations. The pervasive penetrative foliation $\left(S_{2}\right)$ is described as the axial planar fabric, with the implication that $S_{2}$ is also parallel to the co-planar $S_{0} / S_{1}$ fabric (Figure 6). The $F_{2}$ structure is an inclined plunging fold closure characterised by alternating lithologies along strike of the axial trace. $D_{1}$ and $D_{2}$ are therefore co-planar. 


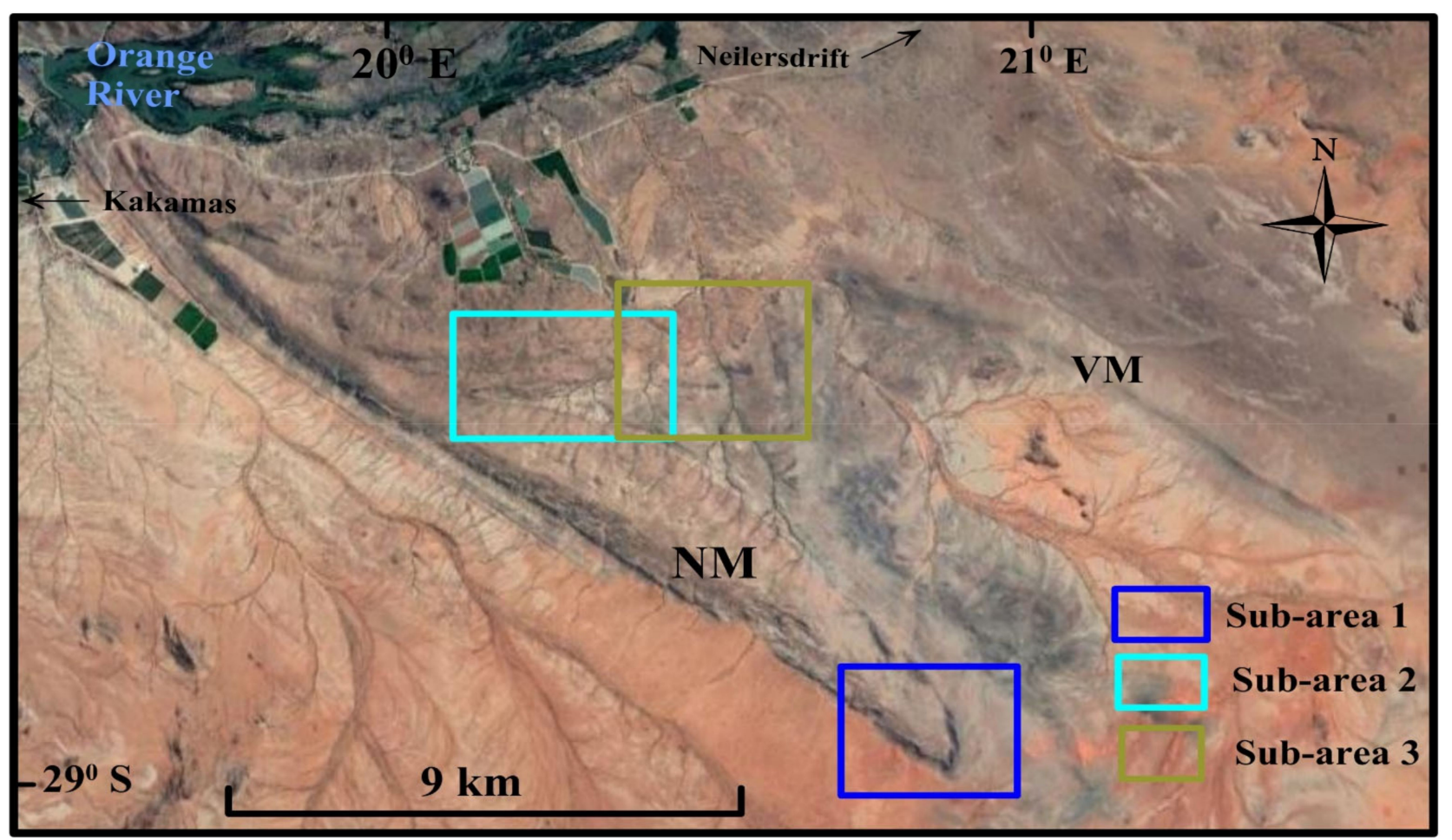

Figure 5. Satellite image showing the location of each sub-area on the Neusberg macrofold in the study area.

$\mathrm{F}_{2}$ folds occurred at $\mathrm{M}_{2}$ metamorphic grade under conditions sufficient enough to overprint the $\mathrm{M}_{1}$ metamorphic event $[16,25,48,59]$, highlighting a significant time span during which the crust reached its thermal peak related to the emplacement of syn- to posttectonic granites in the Kakamas Domain [38]. The $S_{2}$ fabric is regionally sub-horizontal except for the area where it undergoes rotation from sub-horizontal to vertical and is deformed by the later northwest-trending shear zone.

\section{Sub-Area 1}

Sub-area 1 is characterised by a closure (Figure 7A) with its hinge closing towards the southeast with limbs dipping mostly towards the northeast (Figure 7B). The stereonet of foliation $S_{1} / S_{2}$ shows only one cluster of the poles to the planes (Figure $8 \mathrm{~A}$, black solid dots) so that the limbs of the fold in sub-area 1 are parallel to each other, and the structure is described as an isoclinal fold. The main foliation plane dips $53^{\circ}$ towards $038^{\circ}$ (Figure 8A, black great circle) describing a moderately inclined fold. The axial plane trends NW-SE, with the fold axis plunging $37^{\circ}$ towards $055^{\circ}$ (Figure $8 \mathrm{~A}$, blue solid dot) describing a gently northeast plunging fold. The mesoscopic fold in the closure trends towards the southeast (Figure 7E). The stretching lineations $\left(\mathrm{L}_{2}\right)$ plunge to the northeast (Figure 8A, green dots) probably indicating layer parallel slip during folding. The younging direction of strata of the Korannaland Group in sub-area 1 is top-normal defining the southern closure of the Neusberg as a syncline (Figure 7A,B). 


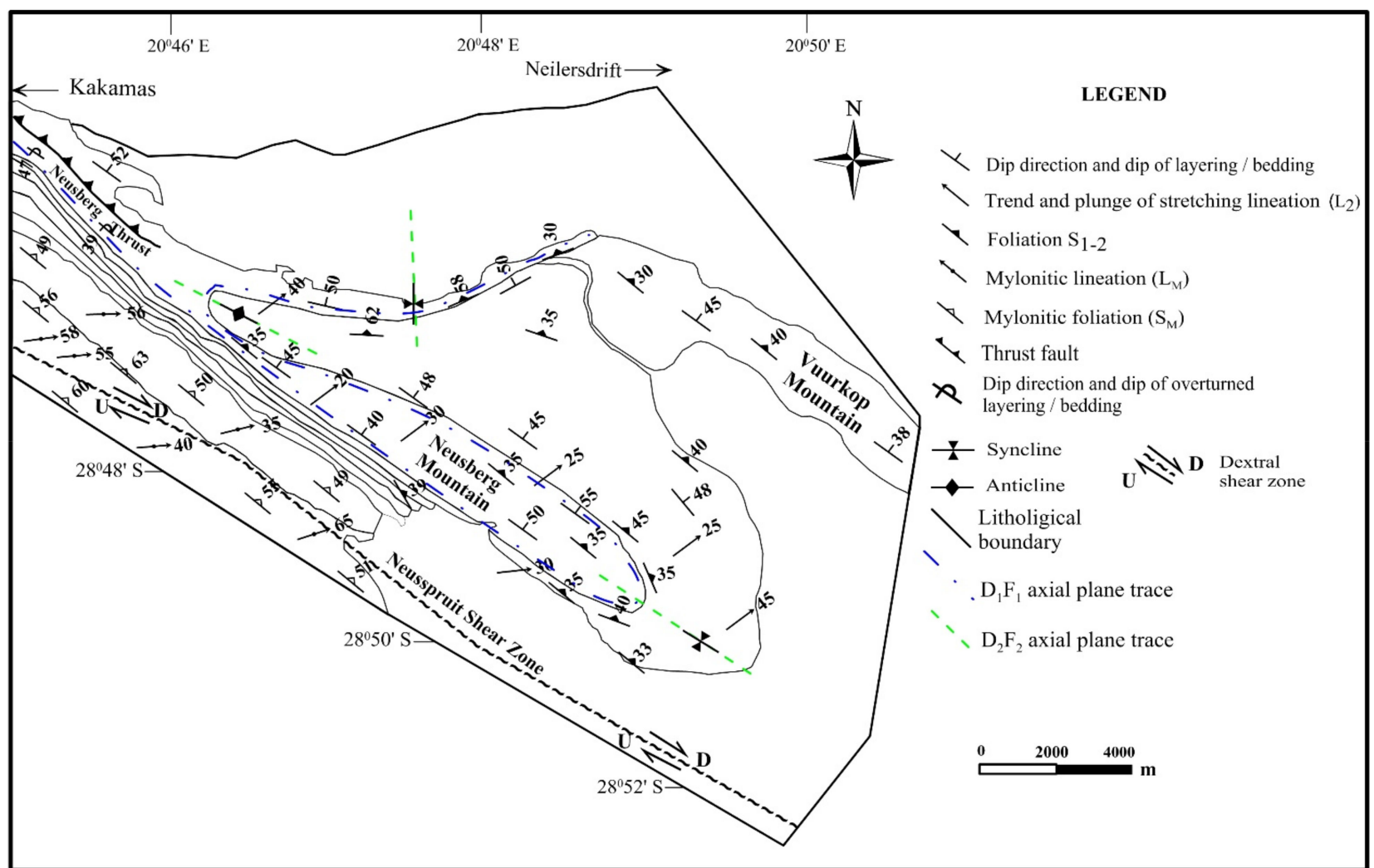

Figure 6. Morphological and geometrical illustration of the Neusberg macrofold in the Kakamas Domain showing the north-westerly trending Neusberg thrust and Neusspruit shear zone. General geometric data of co-planar $F_{1} / F_{2}$ folds are supplied in Figure 8

\section{Sub-Area 2}

Sub-area 2 is characterised by a closure (Figure 7C,D) in the calc-silicate rocks of the Puntsit Formation closing towards the northwest (Figure 7D). Similar to sub-area 1, the stereographic plot shows the main foliation plane dipping $40^{\circ}$ towards $043^{\circ}$ (Figure $8 \mathrm{~B}$, pink great circle) describing a moderately inclined fold. Like in sub-area 1 , the limbs of the fold in this sub-area are initially parallel to each other describing an isoclinal fold. The axial plane trens NW-SE and dips NE, with the fold axis in sub-area 2 plunging $45^{\circ}$ towards $060^{\circ}$ (Figure 7B,E, red dot) describing a gently northeast plunging fold. The axial trace of the parasitic fold trends towards the northwest (Figure 7F). The stretching lineations plunge to the northeast (Figure $8 \mathrm{~B}$, brown dots). The younging of the strata of the Korannaland Group is also top-normal defining the structure in sub-area 2 as an anticline (Figure 7F). 


\section{(A)}
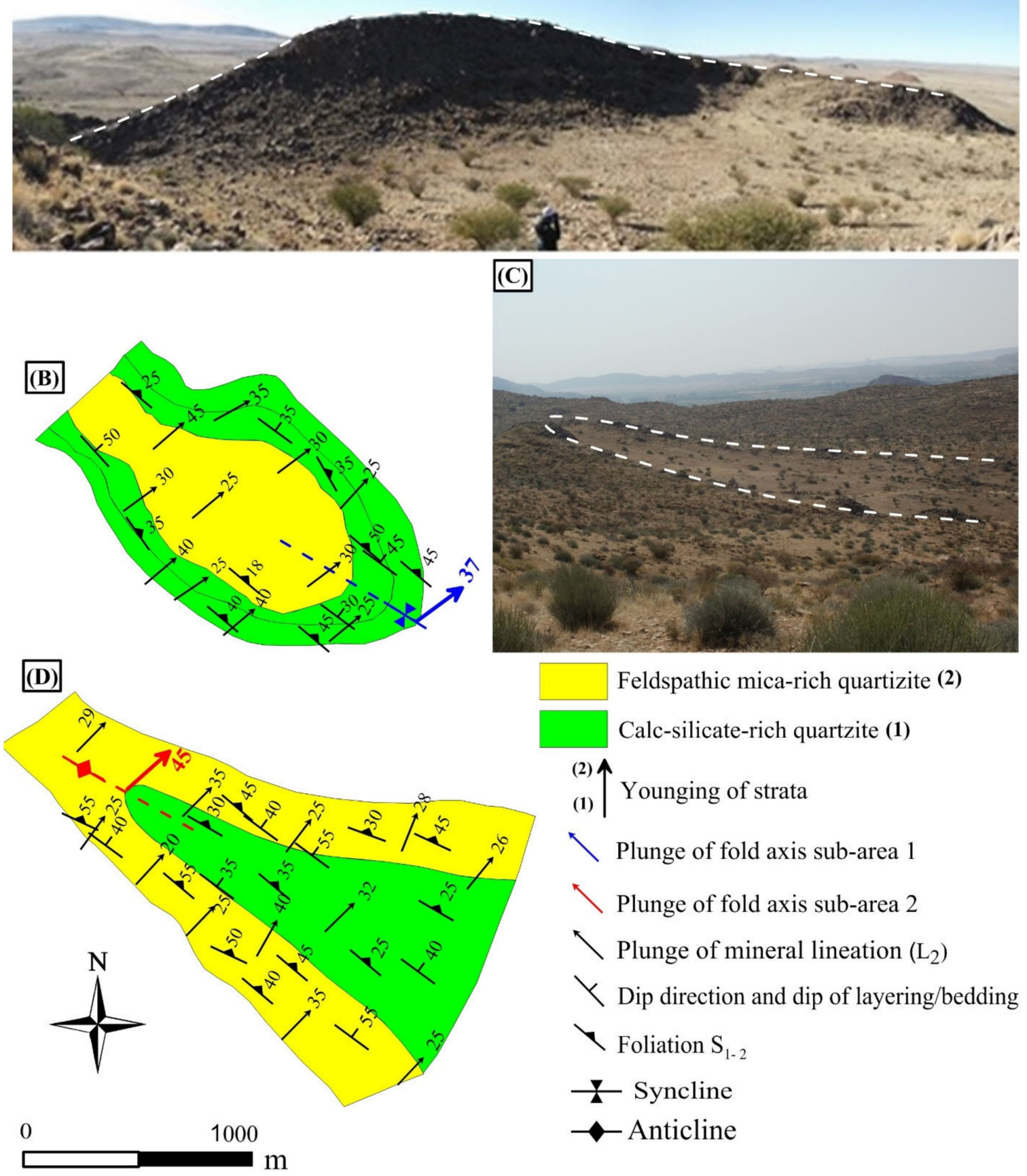

Figure 7. Cont. 

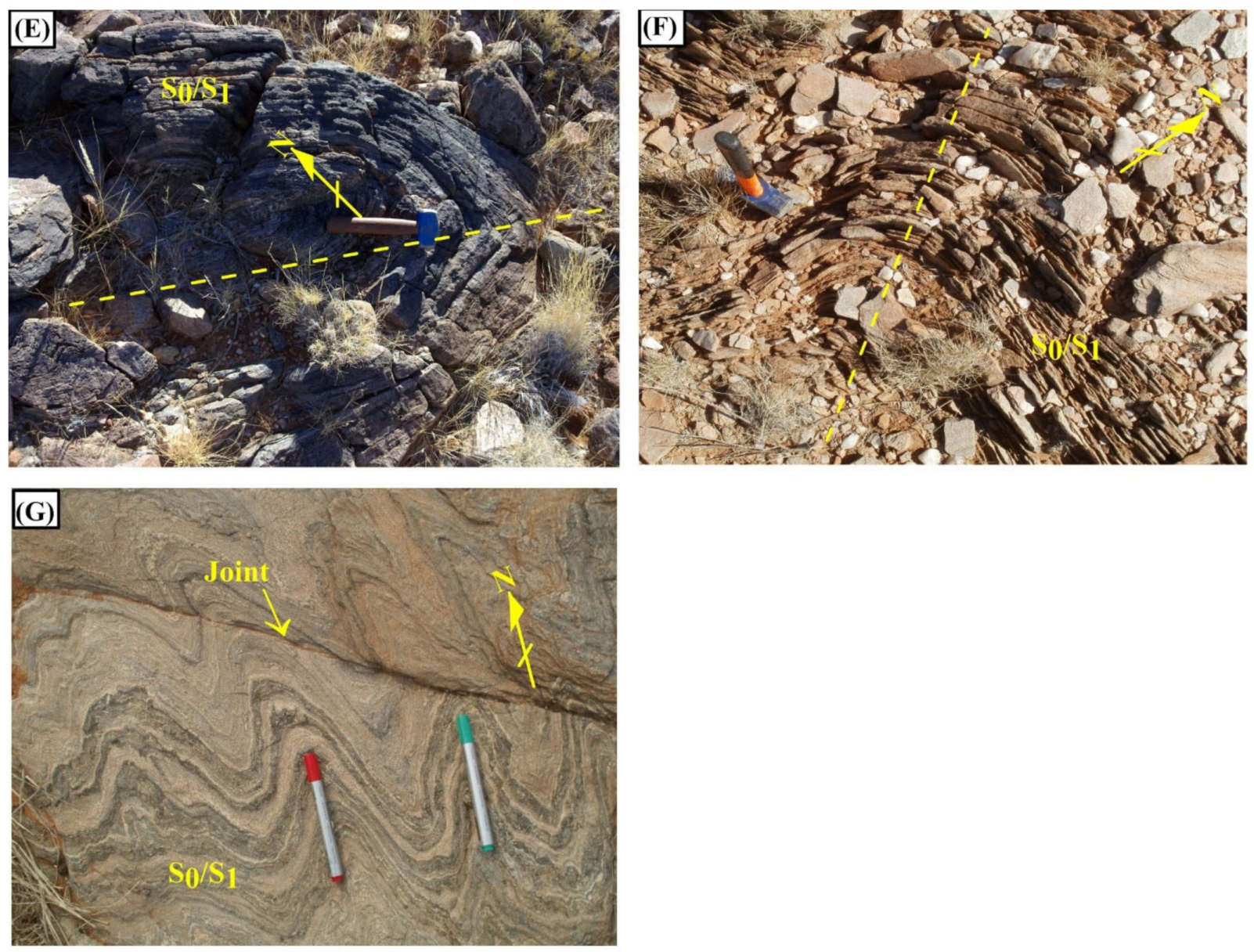

Figure 7. (A) Panoramic view of the closure displayed by the calc-silicate-rich quartzite in sub-area 1. The direction of view is towards the southeast. The white dotted line delineates the synformal structure in sub-area 1. (B) Detailed mapping of the closure outlining a synformal structure in the Neusberg. $S_{0}$ and $S_{1}$ foliations are co-planar, and, together with the fold axis, define a north-easterly plunging synformal structure in subarea 1. (C) Panoramic view of the closure illustrated by the calc-silicate-rich quartzite in subarea 2. The direction of view is towards the northeast. The white dotted line shows an antiformal structure in sub-area 2. (D) Detailed mapping of the closure showing an antiformal structure in the Neusberg. $S_{0}$ and $S_{1}$ foliations are co-planar, and together with the fold axis, define a north-easterly plunging antiformal structure in subarea 2. (E) Outcrop of feldspathic mica-rich quartzite within the closure in sub-area 1 showing a synformal structure. The yellow dashed line indicates an axial trace trending northwest-southeast. (F) Outcrop of feldspathic-mica-rich quartzite displaying an antiformal structure within the closure in sub-area 2. The yellow dashed line shows an axial trace trending towards the northwest-southeast. (G) Parasitic folds within an outcrop of calc-silicate-rich quartzite in sub-area 3. The axial trace of the parasitic folds trend north-south and are illustrated by parallel green and red pen markers.

\section{Sub-Area 3}

Sub-area 3 is located between the Neusberg to the west and Vuurkop to the east. The parasitic folds in this sub-area indicate that the axial plane trends NW-SE (Figure 7G), which is confirmed with data plotted on the stereogram (Figure 8C). The stereographic plot shows two clusters with an interlimb angle of $105^{\circ}$ defining an open fold in sub-area 3 (Figure $8 \mathrm{C}$ ). The best fit girdle is illustrated by the ruby great circle. The axial plane dips $88^{\circ}$ towards $045^{\circ}$ and is trending $317-137^{\circ}$ (Figure $8 \mathrm{C}$, purple dashed great circle) describing an upright fold. The fold axis plunges $59^{\circ}$ towards $318^{\circ}$ (Figure $8 \mathrm{C}$, olive green dot) describing a gently northwest-plunging fold. Stretching lineations $\left(\mathrm{L}_{2}\right)$ were not observed in this sub-area. The structure between the NM and VM is a synformal structure. 


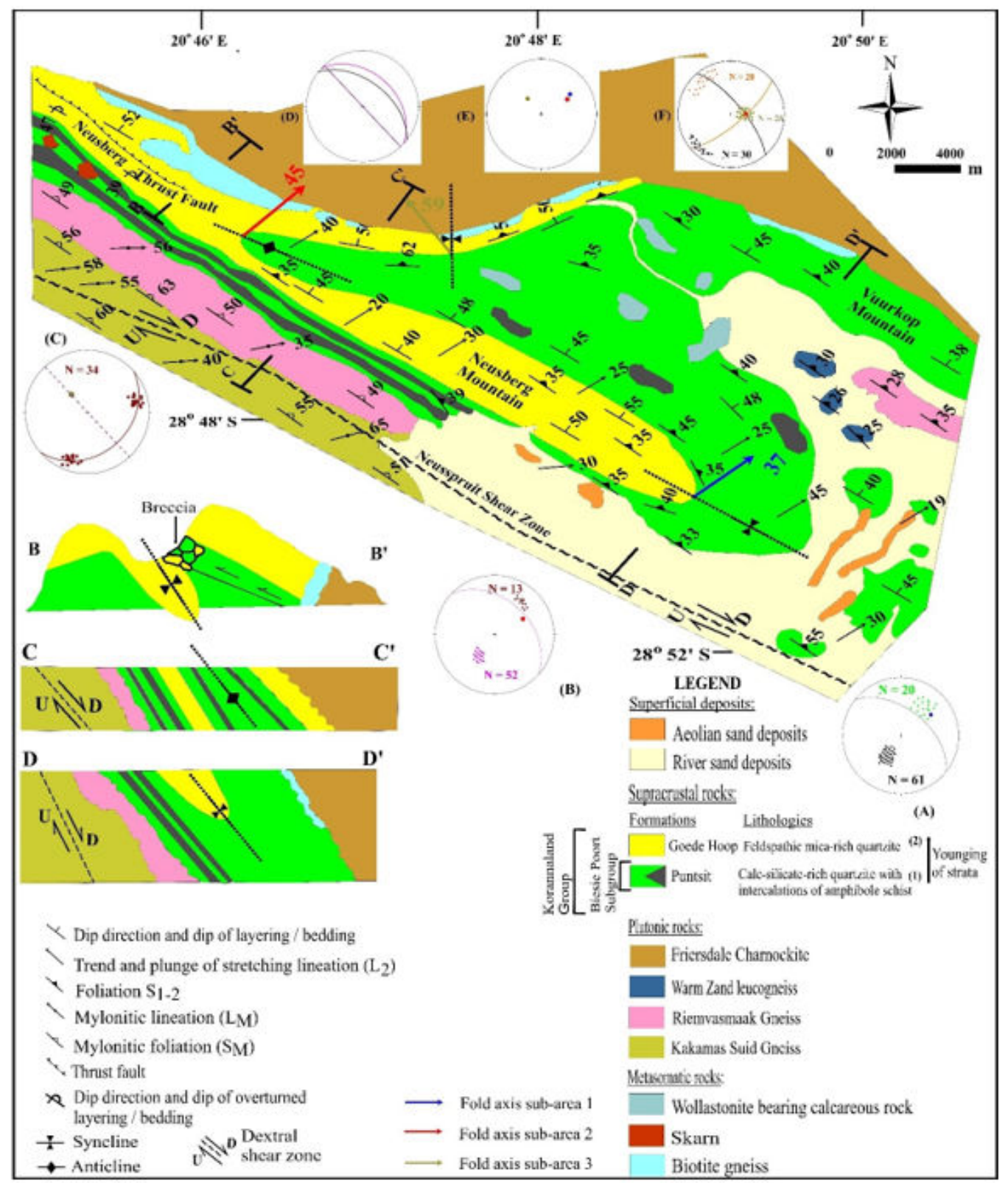

Figure 8. Geological map of the study area displaying the three structural sub-areas within the Neusberg macrofold. Simplified cross-sections B-B' to D-D'. All stereographic projections are equal-area, lower-hemisphere projections. (A) Stereonet shows the plot of poles of $S_{1} / S_{2}$ foliation (black dots), main foliation plane (black great circle; $N=61$ ), and main fold axis (blue dot; $\mathrm{N}=13$ ) of sub-area 1 . The stretching lineations $\mathrm{L}_{2}$ (green dots; $\mathrm{N}=20$ ) plunge towards the northeast in sub-area 1. (B) Stereonet displays the plot of poles of $S_{1} / S_{2}$ foliation (pink dots; $N=52$ ), main foliation plane (pink great circle), and main fold axis (red dot; $\mathrm{N}=11$ ) of sub-area 2. The stretching lineations $\mathrm{L}_{2}$ (brown dots; $\mathrm{N}=13$ ) plunge towards the northeast in sub-area 2. (C) Stereonet showing the plot of poles of the foliation $S_{1} / S_{2}$ (plum dots; $N=41$ ), best-fit girdle (plum great circle), fold axis (olive green dot) and axial plane (purple dashed great circle) of sub-area 3. (D) Stereonet displays the plot of the axial plane of the different sub-areas. (E) Stereonet shows the orientation of the fold axes of the various sub-areas. Each plot of the pole is defined by a specific colour (see legend). (F) Kinematic interpretation of data along the Neusspruit Shear Zone. The stereographic projection shows the plot of poles of mylonitic foliation (black dots; $\mathrm{N}=30$ ), poles of $X Z$-planes (orange dots; $\mathrm{N}=20$ ), and mylonitic elongation lineations (khaki dots; $\mathrm{N}=28$ ). The main mylonitic foliation plane is illustrated by a black great circle, and the XZ-main foliation plane is shown as an orange great circle. The small red triangle is indicative of the mean stretching lineation plunging east. 


\subsection{Thrusting}

Thrusting is developed along the Neusberg Thrust (Figure 8). This fault is a northwestsoutheast-striking structure dipping between $25^{\circ}$ and $75^{\circ}$ in a north-easterly direction. The Neusberg Thrust extends for approximately $3.5 \mathrm{~km}$ in length in the study area and has a footwall composed of calc-silicate and feldspathic mica-rich quartzites. The fault rock is comprised of breccias and defines a well-demarcated thrust zone (Figure 9A). These cataclastic fault rocks contain angular clasts of metasedimentary rocks. The change of the dip orientation from the overall northeast-dipping to upright layers of feldspathic mica-rich quartzite (Figure 9B) is interpreted to be the result of a thrust-fold developed in the hanging wall ramp. Along the Neusberg Thrust, the fault rock assemblage varies in thickness and can reach several meters along this fault. There is no complete thrust front preserved in the study area, but only the southwest-dipping overturned layers of the feldspathic mica-rich quartzite remained on the west side of a well-demarcated valley (Figure 9C).

\subsection{Shearing}

The portion of the Neusspruit Shear Zone investigated in this study is over $10 \mathrm{~km}$ in length and obscured further south by aeolian and river sand deposits. Its trace is defined by a steep northeast-dipping, 1.2 to $1.8 \mathrm{~km}$ wide zone in the study area. This prominent northwest-striking structure is traced further south and north of the study area describing a gently undulating, but regionally consistent northwest-southeast trend. The Neusspruit Shear Zone forms the eastern limit of regional migmatisation and probably marks the western boundary of the Keimoes Suite granites [16], of which the Friersdale Charnockite, classified as a post-tectonic granite ([37] and references therein), intruded the highly deformed supracrustal rocks. Under high-grade conditions, the ductile behaviour of the shear zone is shown by both quartz and feldspar that are deformed as elongate single crystals or aggregates of recrystallised grains (Figure 10C). Horizontal displacement has amounted to between $8.3 \mathrm{~km}$ and $16.5 \mathrm{~km}$ dextrally [25,75]. Some normal dip-slip movement has also been reported to have occurred by [75]. This is confirmed by kinematic analysis (Section 4.5.2).

\subsubsection{Shear Sense Indicators}

Shear sense indicators are illustrated by small-scale structures that are used to determine the shear sense movement in the Neusspruit Shear Zone. They are meso- and microscopic structures from which the sense of relative displacement can be inferred in the shear zone. Such structures include shear bands, the progressive inflexion of the foliation, lozenge-shaped sigmoidal, asymmetric boudins, and isolated asymmetric objects. These shear sense indicators are observed in the XZ-planes perpendicular to the XY-plane and parallel to the mineral stretching lineations. 

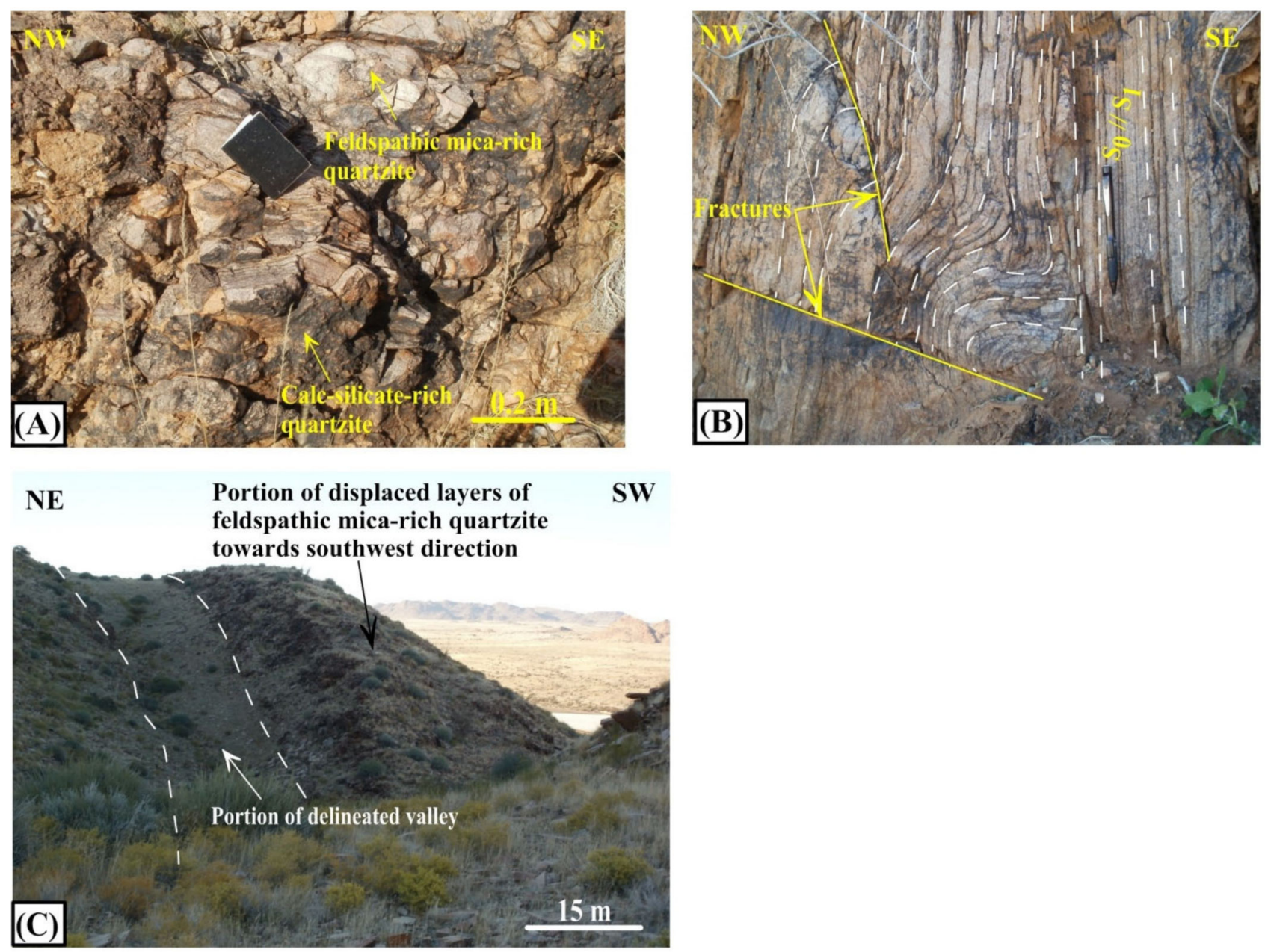

Figure 9. (A) Breccia in the Neusberg Thrust showing a mixture of fragments of feldspathic mica-rich quartzite and calc-silicate-rich quartzite. (B) Steep to overturned and extensively deformed layers of feldspathic mica-rich quartzite in the Neusberg Thrust. (C) A portion of the valley along the Neusberg Thrust. The direction of view is towards the southeast.

The shear bands are identified in the Kakamas Suid Gneiss, with short and closely spaced $\mathrm{mm}$-scale $\mathrm{C}$ shear bands developed obliquely with respect to the shear boundary (Figure 10A). S-C fabrics in the Kakamas Suid Gneiss indicate a dextral shear sense of movement along the Neusspruit Shear Zone. Kinematic indicators, such as progressive dextral inflexion of the foliation at the contact with the shear bands also indicate dextral shear movement (Figure 10B). The photomicrograph of the Kakamas Suid Gneiss shows a lozenge-shaped sigmoid containing recrystallised grains of quartz and feldspar (Figure 10C). The mixture of fine-grained (40-200 $\mu \mathrm{m}$ ) aggregates (Figure 10C; top right side) is similar to a mortar texture, comprising tightly interlocking fine- to medium-grained crystals formed by crushing and recrystallisation of a pre-existing coarser grained rock, which is suggested as evidence of a high strain rate along the Neusspruit Shear Zone, and indicative of dynamic recrystallization in response to ductile deformation as described by [76].

The top and bottom parts of asymmetric boudins in the calc-silicate-rich quartzite (Figure 10D) are subvertical with long axis plunging in the XY-plane indicating a subvertical sense of shearing along the Neusspruit Shear Zone. Isolated asymmetric objects occur in the calc-silicate-rich quartzite as mantled epidotised and/or chloritised plagioclase porphyroclasts (Figure 10E). The core-object geometry shows recrystallization and rotation similar to that of delta ( $\delta$ )-type mantled objects [76,77]. The plagioclase porphyroclast indicates a dextral shear sense of movement (Figure 10E). 


\subsubsection{Kinematic Analysis}

Shear zones play a major role in the deformation of the crust at a variety of scales, as expressions of strain localization during orogeny and rifting, and as reactivated structures [78]. An important characteristic of ductile shear zones is that the wall rocks are moved parallel to the shear zone boundary and that the magnitude of the movement exceeds any stretching or shortening within the wall rocks, e.g., [77]. In this study, the Neusspruit Shear Zone is bounded by deformed supracrustal wall rocks with laterally uniform fabrics. The Kakamas Suid Gneiss in the shear zone is intensely deformed and affected by vortical flow characterised by a vorticity vector (Figure 10G). The XZ-plane, in which the vorticity indicators are observed, is normal to the vorticity vector and known also as the Vorticity Profile Plane (VPP) [79,80]. With deformed wall rock along the shear zone, the flow is described as simple shear [73], and the Vorticity Profile Plane is normal to the $\mathrm{XY}$-plane (defined by the mylonitic foliation $\mathrm{S}_{\mathrm{M}}$; Figure $10 \mathrm{~F}, \mathrm{G}$ ) and parallel to the stretching lineation $\left(\mathrm{L}_{\mathrm{M}}\right)$ characteristics of monoclinic flow symmetry in the Neusspruit Shear Zone. Previous research [77] outlines the application of such characteristics for monoclinic flow symmetry for both undeformed and deformed wall rock in high-grade rocks.

Kinematic analysis using stereographic projections (Figure $8 \mathrm{~F}$ ) displays the main mylonitic foliation $\mathrm{S}_{\mathrm{M}}$ (Figure 8F; black great circle) dipping $73^{\circ}$ towards $050^{\circ}$ describing a steeply inclined structure. The main mylonitic foliation $S_{M}$ shows an approximately similar orientation to that of the main foliation plane in the isoclinal folds in the Neusberg Mountain and is steeply inclined as compared to the moderately inclined supracrustal rocks in the Neusberg. The main foliation on the XZ-plane (Figure $8 \mathrm{~F}$; orange great circle) dips $74^{\circ}$ towards $140^{\circ}$ in the Neusspruit Shear Zone, and its interception with the main mylonitic foliation, $\mathrm{S}_{\mathrm{M}}$, is illustrated by the small red triangle (Figure $8 \mathrm{~F}$ ) plunging east, indicative of the shear direction of the shear zone, and therefore the direction of motion of crustal blocks along the shear zone. The stretching lineations, $\mathrm{L}_{\mathrm{M}}$, in the shear zone plunge east (Figure $8 \mathrm{~F}$, olive green dots) differently to the northeast-plunging stretching lineations (Figure 8A,B, green and brown dots, respectively) in the Neusberg Mountain, indicative of reactivation.

\section{Discussion}

\subsection{Basement/Cover Stratigraphy}

The basement in the Namaqua Sector is of Palaeoproterozoic age (1.8-1.7 Ga) and emplaced during the Orange River Orogeny [5,72], but has not been encountered in the study area. The ages of emplacement of the stratigraphically oldest rocks in the study area, such as the Kakamas Suid Gneiss and Warm Zand leucogneiss, have not yet been investigated. Only the timing of emplacement of the Riemvasmaak Gneiss and Friersdale Charnockite in the Kakamas Domain were investigated by [43] and [22], respectively, using the U-Pb zircon age method. The latter is classified as post-tectonic in the Namaqua Sector $[16,22,37]$. The other intrusive rocks in the study area show a strong pervasive fabric, implying that they must be at least pre- to syn-tectonic, which constrains their time of emplacement.

The timing of deposition of the metasedimentary rocks also remains speculative. They also have a pervasive $S_{2}$ fabric so their age of deposition must be constrained to be prior to the main deformation event implying that they were deposited during pre- to syn-tectonic times. The calc-silicate-rich quartzite of the Puntsit Formation is overlain by the feldspathic mica-rich quartzite of the Goede Hoop Formation, which is classified as the youngest metasedimentary formation. No cross-bedded structures were observed in the calc-silicate-rich quartzite but were identified in the feldspathic mica-rich quartzite (Figure 4B). The younging of strata in the Goede Hoop Formation is defined by upwards fining cycles (Figure 4D) with the younging direction towards the northeast of the isoclinal fold. The protolith for the calc-silicate-rich quartzite, with intercalations of amphibole schist, is likely to be of psammitic and calcareous composition, with intercalations of likely basaltic material. The feldspathic mica-rich quartzite is considered to have had a fluviatile 
type of material as a sedimentary precursor. The metasedimentary rocks were subsequently intensely metamorphosed and deformed during the Namaqua Orogeny.

\subsection{Comparison of Sub-Areas}

The regional crustal stacking due to the northeast-directed indentation of the eastern margin of the Namaqua Sector towards the Kaapvaal Craton, e.g., [27,81], became locked so that no further convergence could take place, resulting in a strike-slip motion along various northwest-southeast-trending shear zones and faults dissecting the Namaqua Sector into different structural domains (Figures 1 and 2). The structural features in the area under consideration are folding, a pervasive northeast-dipping foliation, a northwesterly trending shear zone, and a north-westerly trending thrust fault with vergence to the southwest. The north-easterly plunging moderately inclined isoclinal folds, which define a syncline in sub-area 1 (Figure 7A,B) and an anticline in sub-area 2 (Figure 7C,D), respectively, define the Neusberg macrofold. Investigations by [25] and [6] also described the southern closure of the Neusberg Mountain as an inclined isoclinal fold. The Neusberg and Vuurkop Mountains are separated by a gently north-northwest plunging, and upright open fold defining a synformal structure in sub-area 3 . The northwest-southeast orientation of the axial trace of the mesofold (Figure 7E,F) from subareas 1 and 2, respectively, is similar to, but differs from, the north-south to northwest-southeast-oriented axial trace identified in the parasitic folds (Figure 7G) of sub-area 3. The stretching lineations $\left(\mathrm{L}_{1}\right)$ are particularly well developed in sub-areas 1 and 2 and plunge north-easterly in the Neusberg macrofold but are non-existent in sub-area 3 . The axial traces of the isoclinal folds in sub-areas 1 and 2 in the Neusberg macrofold are aligned with the Neusspruit Shear Zone due to further compression and crustal shortening. The stereoplot of the axial planes of sub-areas 1 and 2 shows approximately the same north-easterly oriented dip direction in the Neusberg macrofold with the axial plane in sub-area 3 marginally more NNE-oriented, with the fold axis plunging toward the NW as opposed to the NE for the folds in sub-areas 1 and 2 (Figure 8D). The change of the orientation of the axial plane from the northeast in sub-areas 1 and 2 to marginally more north-northwest, as well as a change in the orientation of the fold axis in sub-area 3 (Figure 8D) is possibly related to the emplacement of the Friersdale Charnockite of the Keimoes Suite within the supracrustal rocks. The isoclinal nature of the folds in sub-areas 1 and 2 suggests a greater degree of strain compared to the open fold in sub-area 3, probably related to the proximity to the Neusspruit Shear Zone, which may have acted as some sort of barrier to deformation.

\subsection{Metamorphism and Deformation}

The study area is characterised by high- $T$, low- $P$ granulite facies metamorphic conditions in the Kakamas Domain [25]. Similar metamorphic conditions were recognised in other areas and associated with clockwise $P-T$ paths recorded by means of mineral equilibria, e.g., [21,48,58,59]. According to [25], there were three main metamorphic and deformation events that occurred in the Kakamas Domain (Table 2). In this study, we reinterpret the polyphase metamorphic and deformation events in this part of the Domain, of which four main events were recognised (Table 2). 


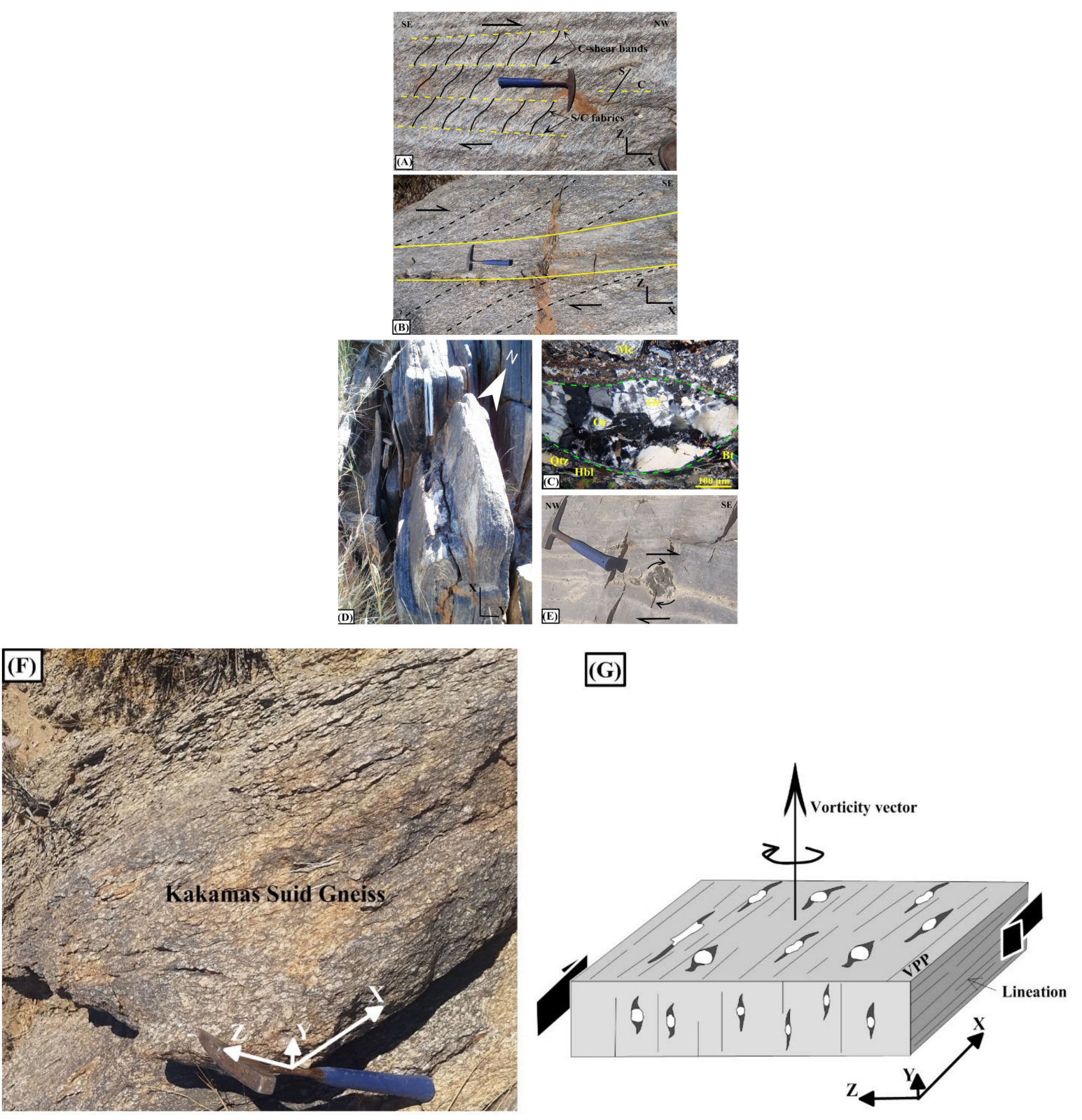

Figure 10. Structural and kinematic indicators along and adjacent to the Neusspruit Shear Zone. (A) S-C fabrics indicating dextral shear movement in the Kakamas Suid Gneiss along the Neusspruit Shear Zone. (B) Northwest-trending dextral shear zone in the Kakamas Suid Gneiss: Dextral shear movement is indicated by the progressive inflexion at the contact with the shear zone. (C) Photomicrograph of the Kakamas Suid Gneiss showing a mixture of very fine-grained crystals (top right-hand corner) indicative of shearing adjacent to the Neusberg Mountain, as well as well-delineated quartz/feldspar augen. Abbreviations: $\mathrm{Qtz}=\mathrm{Quartz} ; \mathrm{Or}=$ Orthoclase; $\mathrm{Mc}=$ Microcline; $\mathrm{Hbl}=$ Hornblende; $\mathrm{Bt}=\mathrm{Biotite}$. (D) Boudinage traces in the calc-silicate-rich quartzite with long axis plunging in the XY-plane indicates an oblique sense of shear for the Neusspruit Shear Zone (white line is the edge of the notebook). (E) Highly epidotised $\delta$-type plagioclase porphyroclast within the calc-silicate-rich quartzite. The tails contain traces of epidote. Dextral vorticity is indicated. (F) Outcrop of Kakamas Suid Gneiss showing well-defined mylonitic foliation illustrated in the XY-plane. (G) Sketch of monoclinic shear. The transport direction and, similarly, the vorticity profile plane (VPP) are parallel to the lineations. 


\subsection{1. $\mathrm{M}_{1}$ and $\mathrm{D}_{1}$ Events}

The $\mathrm{M}_{1}$ peak metamorphic event in the Kakamas Domain is characterised by granulite facies conditions estimated at $T=\sim 800{ }^{\circ} \mathrm{C}$ and $P=5.5 \mathrm{kbar}$ [25] (Table 2). Similar metamorphic conditions were determined north of Pofadder $\left(800-900{ }^{\circ} \mathrm{C}\right.$ and $\sim 5 \mathrm{kbar}$ [48,49], and dated 1220-1180 Ma [38,48]. The peak metamorphic paragenesis is reflected by garnetcordierite-orthoclase-spinel-quartz in spinel + quartz-bearing metapelites [48]. The $\mathrm{D}_{1 \mathrm{a}}$ deformation event is described as the early event related to oceanic basin closure in the eastern Namaqua Sector $[1,5,6,60]$. The timing of basin closure was determined as occurring at $1197 \pm 5 \mathrm{Ma}$ based on metamorphic overgrowths on detrital zircons [20]. The $\mathrm{D}_{1 \mathrm{a}}$ event is characterised by the development of the Hartbees River Thrust recognised as an inter-domain structure between the Kakamas Domain and Bushmanland Subprovince [4-6]. The $\mathrm{D}_{1 \mathrm{~b}}$ deformation event is characterised by compression recognised in all the rocks below the Goede Hoop Formation. Some relic intrafolial folds have been observed in the $S_{1}$ foliation in the Puntsit Formation, confirming the penetrative transposition of $S_{0}$ into $S_{1}$.

\subsection{2. $\mathrm{M}_{2}$ and $\mathrm{D}_{2}$ Events}

The $\mathrm{M}_{2}$ metamorphic event is ascribed to slow cooling and heating episodes at near constant mid-crustal pressure conditions [48]. The peak metamorphism was followed by isobaric cooling to at least $700-660^{\circ} \mathrm{C}$, e.g., [48] during $\mathrm{M}_{2}$ (Table 2). The paragenesis during the $\mathrm{M}_{2}$ event is defined by cordierite-garnet-orthoclase-hornblende-biotite-sillimanite in the kinzingites [25]. Previous research [48] confirmed that the presence of biotite and sillimanite is related to isobaric cooling of peak metamorphic cordierite and garnet. The $\mathrm{M}_{2}$ metamorphic event is associated with the emplacement of the Riemvasmaak Gneiss dated at $1151 \pm 14 \mathrm{Ma}$ [43]. A similar age was established for the Rooipad Granite at $1155 \pm 7 \mathrm{Ma}$ [4]. In the study area, contact rocks, such as the skarn and wollastonitebearing calcareous rocks (Figure 3), occur as spotty rocks in the supracrustal rocks as the result of a fluid-induced compositional change due to the episodic emplacement of syn-tectonic granitoids. The paragenesis is defined by locally occurring wollastonite, as well as skarn within the calc-silicate-rich quartzite (Figure 3).

Table 2. Tectonic framework of the study area in the Kakamas Domain, eastern Namaqua Sector.

\begin{tabular}{|c|c|c|c|c|c|c|c|}
\hline $\begin{array}{l}\text { Deformation } \\
\text { Event }\end{array}$ & Age (Ma) & Magmatism & Metamorphism & Structure & Characteristic & Fabric & $\begin{array}{l}\text { Deformation } \\
\text { Style }\end{array}$ \\
\hline $\mathrm{D}_{1 \mathrm{a}}$ & $\sim 1200$ & & $\begin{array}{c}{ }^{\mathrm{a}} T=\sim 800{ }^{\circ} \mathrm{C} \\
P=5.5 \mathrm{kbar}\end{array}$ & $\begin{array}{l}\text { Inter-terrane } \\
\text { thrust (HBRT) }\end{array}$ & $\begin{array}{l}\text { Compressional } \\
\text { deformation }\end{array}$ & & $\begin{array}{l}\text { start of } \\
\text { progressive } \\
\text { shear }\end{array}$ \\
\hline $\mathrm{D}_{1 \mathrm{~b}}$ & & & & $\mathrm{~F}_{1}$ folding & $\begin{array}{l}\mathrm{D}_{1 \mathrm{~b}} \mathrm{~F}_{1} \text { folds, } \\
\text { transposition } \\
\mathrm{S}_{0} \text { into } \mathrm{S}_{1}\end{array}$ & $S_{1}$ shear fabric & $\begin{array}{l}\text { progressive } \\
\text { shear } \\
\text { continuing }\end{array}$ \\
\hline $\mathrm{D}_{2}$ & $\sim 1155-1110$ & $\begin{array}{l}\text { Syn-tectonic } \\
\text { plutons }\end{array}$ & $\begin{array}{c}\mathrm{b}^{\mathrm{b}} T=700-660^{\circ} \mathrm{C} \\
P=5.5 \mathrm{kbar}\end{array}$ & $\mathrm{F}_{2}$ folding & $\begin{array}{c}\mathrm{D}_{1 \mathrm{~b}} \mathrm{~F}_{1} \text { folds, } \mathrm{S}_{2} \\
\text { axial planar, } \\
\mathrm{S}_{1} / \mathrm{S}_{2} \\
\text { co-planar }\end{array}$ & $\begin{array}{c}S_{2} \text { regional } \\
\text { fabric }\end{array}$ & $\begin{array}{l}\text { Main } \\
\text { progressive } \\
\text { shear }\end{array}$ \\
\hline$D_{3}$ & $\begin{array}{l}{ }^{c} 1113 \text { to } \\
1080\end{array}$ & $\begin{array}{l}\text { Post-tectonic } \\
\text { Friersdale } \\
\text { Charnockite of } \\
\text { the Keimoes } \\
\text { Suite }\end{array}$ & $\begin{array}{c}{ }^{\mathrm{d}} T=\sim 640-550{ }^{\circ} \mathrm{C} \\
P=4.8 \mathrm{kbar}\end{array}$ & $\begin{array}{c}\text { Friersdale } \\
\text { Charnockite } \\
\text { into } D_{1 b} \text { fold } \\
\text { hinge }\end{array}$ & & $\begin{array}{c}\text { Weakly } \\
\text { defined fabric }\end{array}$ & $\begin{array}{l}\text { Progressive } \\
\text { shear } \\
\text { terminated }\end{array}$ \\
\hline $\mathrm{D}_{4}$ & & & $\begin{array}{l}{ }^{\mathrm{e}} T=\sim 350{ }^{\circ} \mathrm{C} \\
P=\sim 3.5 \mathrm{kbar}\end{array}$ & $\begin{array}{c}\text { Reactivation of } \\
\text { intra-terrane } \\
\text { thrust, } \\
\text { formation of } \\
\text { transcurrent } \\
\text { shear zone }\end{array}$ & $\begin{array}{l}\text { Northwest- } \\
\text { trending } \\
\text { steeply } \\
\text { inclined shear } \\
\text { zone, shear } \\
\text { direction } \\
\text { towards east }\end{array}$ & $\begin{array}{l}\text { Deformation of } \\
\text { adjacent } \\
\text { pre-existing } \\
\text { structure }\end{array}$ & $\begin{array}{l}\text { Start of trans- } \\
\text { pressional } \\
\text { shearing }\end{array}$ \\
\hline
\end{tabular}


The timing of emplacement of the syn-tectonic granites places the $\mathrm{D}_{2}$ event between $1151 \pm 14 \mathrm{Ma}$ and $1105 \mathrm{Ma}$ based on the timing of intrusion of late- to post-tectonic Keimoes Suite granitoids relative to the pre- to syn-tectonic granitic gneisses [37]. The $D_{2}$ event is characterised by co-planar $S_{0} / S_{1}$ fabric and $S_{2}$ axial planar fabric defining northwest-southeast-striking $\mathrm{F}_{2}$ folds in the Neusberg macrofold. The stretching lineations $\left(\mathrm{L}_{2}\right)$ trend northeast parallel to the fold axes of isoclinal folds in the Neusberg Mountain. The lineations plunge towards the northeast indicative of layer parallel slip during folding. Towards the end of the $\mathrm{D}_{2}$ event, it is envisaged that the Neusberg thrust developed because of continued shortening, causing some stacking in the Goede Hoop Formation.

\subsection{3. $\mathrm{M}_{3}$ and $\mathrm{D}_{3}$ Events}

The $\mathrm{M}_{3}$ metamorphic event is characterised by $T=\sim 640-550{ }^{\circ} \mathrm{C}$ and $P=4.8 \mathrm{kbar}$ [21] (Table 2) and is associated with magmatism between 1113 and 1080 Ma classified as posttectonic $[22,35,37,43]$ (Table 2) in the Kakamas Domain. The intrusion of the supracrustal rocks by the Friersdale Charnockite is illustrated by a contact rock, in places identified as the biotite gneiss (Figure 3 ). The $\mathrm{D}_{3}$ event is characterised by a weakly defined fabric in the Friersdale Charnockite.

\subsection{4. $\mathrm{M}_{4}$ and $\mathrm{D}_{4}$ Events}

The $\mathrm{M}_{4}$ metamorphic event is characterised by $T=\sim 350{ }^{\circ} \mathrm{C}$ and $P=\sim 2.5 \mathrm{kbar}$ [25] (Table 2) defining greenschist facies conditions associated with the paragenesis of quartzorthoclase-biotite-muscovite-chlorite-plagioclase that occurred in the feldspathic micarich quartzite of the Goede Hoop Formation, with the presence of chlorite indicating retrograde metamorphic conditions [25]. Within altered undifferentiated gneisses, alkali feldspars are sericitised and biotite is altered into chlorite. Metamorphism is estimated to have occurred between $1040 \mathrm{Ma}$ and $1020 \mathrm{Ma}$ [48,64] (Table 2). The $\mathrm{D}_{4}$ event is characterised by dextral strike-slip faulting along the Neusspruit Shear Zone $[1,5,19,56,60]$.

\subsection{Tectonic Evolution}

The tectonic evolution of the Kakamas Domain in the eastern Namaqua Sector is characterised by the southwest vergence and thrusting of this domain onto the Bushmanland Subprovince along the Hartbees River Thrust Zone [5]. This nappe trends mostly northwest-southeast and dips towards the northeast at about $20-75^{\circ}$ with stretching lineations that plunge towards the northeast. The metamorphism affecting the nappe is of granulite facies characterised by clockwise $P$-T- $t$-paths, established by the aid of mineral equilibria $[21,58,59]$. The peak metamorphic conditions have been estimated at $T=\sim 800{ }^{\circ} \mathrm{C}$ and $P=5.5$ kbar $[25,48,49]$ and dated between 1220-1100 Ma [38,48] during the Namaqua Orogeny. This metamorphic gradient is understood to be caused by early thrusting and thickening of the crust owing to tectonic stacking, associated with advective heat transfer related to large volumes of intrusive rocks, e.g., [5]. This interpretation is supported by $[38,48,49]$ confirming the granulite facies conditions experienced by the Kakamas Domain. In this study, the general map pattern (Figures 6 and 8) indicates not only extensional tectonics, as established by $[38,48,49]$ that occurred in the Kakamas Domain during deposition of the Korannaland Group, but also compressional tectonics, leading to tectonic stacking and magmatic accretion, as well as thickening of the crust. Previous research [5] confirm both extensional and compressional tectonics in the central, eastern, and northern parts of the Namaqua Sector. The Palaeoproterozoic basement emplaced at about 1.8-1.7 Ga during the Orange River Orogeny [5,72] was potentially reworked and mixed with juvenile Mesoproterozoic material in the Namaqua Sector during the Namaquan Orogeny, e.g., [3,33,37,38,48,72,82].

Based on available ages and field relationships, the granitic gneisses, such as the Riemvasmaak and Kakamas Suid Gneisses, are pre- to syn-tectonic due to their deformed nature, whereas the Friersdale Charnockite is post-tectonic because it is undeformed. The overall thickness of the metasedimentary rocks, which varies between $140 \mathrm{~m}$ and $200 \mathrm{~m}$ in 
the Goede Hoop Formation, and about $30 \mathrm{~m}$ to $80 \mathrm{~m}$ in the Puntsit Formation, excluding any repetition due to isoclinal folding as demonstrated in the Neusberg Mountain, suggests a restricted and narrow basin with limited sedimentary input. The protoliths to the calcsilicate and feldspathic mica-rich quartzites were likely carbonates and/or immature marls, and sandstones, respectively. The occurrence of the amphibole schist as intercalations in the calc-silicate-rich quartzite is suggestive of varying pulses of deposition of both clastic continental and volcanic materials in the Kakamas Domain.

Continued shortening led to thrusting, of which the overturned ramp dips southwesterly as opposed to the prominent north-easterly dipping foliation planes in the Neusberg. The timing of early compressional events is related to the early Namaquan Orogeny, as recognised by [43] elsewhere in the Kakamas Domain. The occurrence of isoclinal folds in the Neusberg suggests that a considerable amount of stress was applied during the $\mathrm{D}_{2}$ event ([25] and this study), associated with the emplacement of the granite gneisses between $1151 \mathrm{Ma}$ [43] and $1125 \mathrm{Ma}[35,37]$ in the Kakamas Domain. Previous research [37] reported similar ages across the boundary in the Areachap Domain where the well-foliated Louisvale Tonalite was emplaced at $1125 \mathrm{Ma}$, providing the maximum age for the main $\mathrm{D}_{2}$ Namaquan deformation. The minimum age for the $\mathrm{D}_{2}$ Namaquan deformation in the eastern Namaqua Sector is constrained by the post-tectonic Keimoes Suite for which the oldest reliably dated member, the weakly foliated Keboes Granite, has been dated at 1105 Ma [37].

Subsequent intrusion is related to the $\mathrm{D}_{3}$ event and is characterised by the emplacement of the voluminous post-tectonic Friersdale Charnockite of the Keimoes Suite (at 1080 Ma) [22]. A late transcurrent northwest-southeast-trending shear zone occurred by reactivation of the $D_{1 b}$ structure into a steeply inclined and deeply rooted intra-domain shear zone between 1040 Ma and 1020 Ma defining the Neusspruit Shear Zone [25,26]. The Neusspruit Shear Zone has a dextral sense of movement, and its extension further north of the Orange River [5,6,25,26,31,75] constitutes a regional discontinuity in the Kakamas Domain.

\section{Conclusions}

1. The central part of the Namaqua Sector was subjected to intense deformation under high-grade metamorphic conditions correlated to granulite facies, but also shows greenschist facies overprints denoting the metamorphic nature during the 1.2-1.0 Ga Namaquan Orogeny. The compressional orogenic phase is associated with $D_{1}$ and $D_{2}$ events during which northeast-southwest-directed shortening resulted in southwest-directed thrusting illustrated by a late intra-domain thrust and southwest verging isoclinal folds in the Neusberg of the Kakamas Domain. The post-tectonic Friersdale Charnockite of the Keimoes Suite is emplaced during the $\mathrm{D}_{3}$ deformation event in the study area. The Neusspruit Shear Zone is of a monoclinic nature and is described as a deeply rooted structure with shear direction towards the east.

2. The findings obtained have provided indications of the processes that occurred at the western margin of the Archean Kaapvaal Craton, and contributed to the understanding of the tectonic evolution of the Kakamas Domain within the Namaqua Sector. In this detailed study of a rather small area, the presence of a structure that forms part of the regional-scale structural pattern in the Kakamas Domain, together with the Neusspruit Shear Zone, and the Neusberg Thrust Fault, a presumed regional-scale thrust, were recognised to form part of an intensely flattened narrow basin in the eastern Namaqua Sector.

3. The general flattened pattern of the Neusberg Range associated with isoclinal folding represents a bulk of strain along with a monoclinic symmetry in the Neusspruit Shear Zone. The strain and vorticity indices suggest a transpressional shearing across the Neusspruit Shear Zone and adjacent regions.

4. The $\sim 1.2$ to $1.8 \mathrm{~km}$-wide, northwest-southeast-striking dextral-dominated Neusspruit Shear Zone constitutes a western regional boundary for the Korannaland Group. The Neusspruit Shear Zone is composed of steep, narrow zones of relatively high strain, such as high-grade gneiss, characterised by ductile deformation and penetrative strain. Although 
this study does not investigate strain analysis, further study on a regional scale based on finite strain and kinematic vorticity values are essential to describe the ductile flow type across the Neusspruit Shear Zone and adjacent regions.

5. New zircon SHRIMP U-Pb age, LA-ICP-MS, and isotopic analyses are required for both the magmatic and supracrustal rocks in the Kakamas Domain and constitute further studies. This will significantly contribute to the understanding of the petrogenetic processes, the timing of emplacement of the granitic gneisses, and the timing of deposition of the supracrustal rocks, respectively, as well as the approximate timing of occurrence of the shear zone. In addition, geochemical analyses should be applied to help constraint the tectonic setting and geodynamic role of the Kakamas Domain in the eastern Namaqua Sector during the 1.2-1.0 Ga Namaqua Orogeny.

Supplementary Materials: The following are available online at https:/ /www.mdpi.com/article/ $10.3390 / \mathrm{min} 11070759 / \mathrm{s} 1$, Table S1: Datasets for the various sub-areas adjacent to the Neusberg Mountain in the central Kakamas Domain, Namaqua Sector, South Africa.

Author Contributions: Conceptualization, J.v.B.D.; methodology, C.S.T.S. and J.v.B.D.; software, J.v.B.D.; validation, C.S.T.S., J.v.B.D. and R.B.; formal analysis, C.S.T.S.; investigation, C.S.T.S.; resources, J.v.B.D. and R.B.; data curation, C.S.T.S., J.v.B.D. and R.B.; writing- original draft preparation, C.S.T.S.; writing - review and editing, J.v.B.D. and R.B.; visualization, C.S.T.S. and J.v.B.D.; supervision, J.v.B.D. and R.B.; project administration, J.v.B.D. and R.B.; funding acquisition, J.v.B.D. and R.B. All authors have read and agreed to the published version of the manuscript.

Funding: This research was supported by the Inkaba yeAfrica/Iphakade program, a program of the Department of Science and Technology (DST) and the National Research Foundation (NRF) of South Africa. This is Inkaba yeAfrica/Iphakade contribution number 169. Annual incentive funds (grant no. 86005) of South Africa's National Research Foundation (NRF) to Russell Bailie also helped fund this project and are gratefully acknowledged.

Data Availability Statement: Google Earth ${ }^{\mathrm{TM}}$ images of the study area are available at Google Earth ${ }^{\mathrm{TM}}$.

Acknowledgments: The authors would like to thank the owner of Karstens Boerderye in Koekoeb, Kakamas for offering accommodation and generously allowing us to perform the field studies. Richard Harrison and Janine Botha, née Becorney of the Department of Earth Sciences, University of the Western Cape, are thanked for assisting with petrographic thin section preparation.

Conflicts of Interest: The authors declare no conflict of interest. The funders had no role in the design of the study; in the collection, analyses, or interpretation of data; in the writing of the manuscript, or in the decision to publish the results.

\section{References}

1. Colliston, W.P.; Schoch, A.E. Wrench-shearing during the Namaqua Orogenesis-a Mesoproterozoic window on late-phase deformation during Rodinia assembly. Precambr. Res. 2013, 233, 44-58. [CrossRef]

2. Spencer, C.J; Cawood, P.A.; Hawkesworth, C.J.; Prave, A.R.; Roberts, N.M.W.; Horstwood, M.S.A.; Whitehouse, M.J. Generation and preservation of continent crust in the Grenville Orogeny. Geosci. Front. 2015, 6, 357-372. [CrossRef]

3. Macey, P.H.; Thomas, R.J.; Minnaar, H.M.; Gresse, P.G.; Lambert, C.W.; Groenewald, C.A.; Miller, J.A.; Indingo, J.; Angombe, M.; Shifotoka, G.; et al. Origin and evolution of the 1.9 Ga Richtersveld Magmatic Arc, SW Africa. Precambr. Res. 2017, 292, 417-451. [CrossRef]

4. Colliston, W.P.; Cornell, D.H.; Schoch, A.E.; Praekelt, H.E. Geochronological constraints on the Hartbees River Thrust and Augrabies Nappe: New insights into the assembly of the Mesoproterozoic Namaqua-Natal Province of Southern Africa. Precambr. Res. 2015, 265, 150-165. [CrossRef]

5. Colliston, W.P.; Schoch, A.E.; Cole, J. The Grenvillian Namaqua fold belt adjacent to the western Kaapvaal Craton: 2. Archean Craton and supercontinent connections. Precambr. Res. 2017, 300, 289-314. [CrossRef]

6. Mathee, H. Structural-Stratigraphic Investigation of an Area Near Kakamas and Environs, Namaqua Mobile Belt. Master's Thesis, University of the Free State, Bloemfontein, South Africa, 2017.

7. Jacobs, J.; Pisarevsky, S.; Thomas, R.J.; Becker, T. The Kalahari Craton during the assembly and dispersal of Rodinia. Precambr. Res. 2008, 160, 142-158. [CrossRef]

8. Dalziel, I.W.; Mosher, S.; Gahagan, L.M. Laurentia-Kalahari Collision and the assembly of Rodinia. J. Geol. 2000, 108, 499-513. [CrossRef] 
9. Li, Z.X.; Bogdanova, S.V.; Collins, A.S.; Davidson, A.; De Waele, B.; Ernst, R.E.; Fitzsimons, I.C.W.; Fuck, R.A.; Gladkochub, D.P.; Jacobs, J.; et al. Assembly, configuration, and break-up history of Rodinia: A synthesis. Precambr. Res. 2008, 160, 179-210. [CrossRef]

10. McLelland, J.M.; Selleck, B.W.; Bickford, M.E. Review of the Proterozoic evolution of the Grenville Province, its Adirondack outlier, and the Mesoproterozoic inliers of the Appalachians. Mem. Geol. Soc. Am. 2010, 206, 1-29.

11. Hartnady, C.J.H.; Joubert, P.; Stowe, C.W. Proterozoic crustal evolution in southwestern Africa. Episodes 1985, 8, 236-244. [CrossRef]

12. Thomas, R.J.; Cornell, D.H.; Moore, J.M.; Jacobs, J. Crustal evolution of the Namaqua-Natal metamorphic Province, southern Africa. S. Afr. J. Geol. 1994, 97, 8-14.

13. Cornell, D.H.; Thomas, R.J.; Moen, H.F.G.; Reid, D.L.; Moore, J.M.; Gibson, R.L. The Namaqua-Natal Province. In The Geology of South Africa; Johnson, M.R., Anhaeusser, C.R., Thomas, R.J., Eds.; Geological Society of South Africa, Johannesburg/Council for Geoscience: Pretoria, South Africa, 2006; pp. 325-379.

14. Miller, R. Review of Mesoproterozoic magmatism, sedimentation and terrane amalgamation in Southwestern Africa. S. Afr. J. Geol. 2012, 115, 417-448. [CrossRef]

15. Colliston, W.P.; Schoch, A.E. Proterozoic metavolcanic rocks and associated metasediments along the Orange River in the Pofadder Terrane, Namaqua metamorphic belt. S. Afr. J. Geol. 1996, 99, 1-17.

16. Moen, H. The Geology of the Upington Area. Map Sheet Explanation, 2820. Scale 1:250 000; Council for Geoscience: Pretoria, South Africa, 2007; p. 160.

17. Coney, P.J.; Jones, D.L.; Monger, J.W.H. Cordilleran suspect terranes. Nature 1980, 288, 467-480. [CrossRef]

18. Joubert, P. The Namaqualand Metamorphic Complex. In Precambrian of the Southern Hemisphere. Developments in Precambrian Geology 2; Hunter, D.R., Ed.; Elsevier: Amsterdam, The Netherlands, 1981; pp. 671-705.

19. Blignault, H.J.; van Aswegen, G.; van der Merwe, S.W.; Colliston, W.P. The Namaqualand geotraverse and environs: Part of the Proterozoic Namaqua Mobile Belt. In Namaqualand Metamorphic Complex; Botha, B.V., Ed.; Special Publication of the Geological Society of South Africa: Johannesburg, South Africa, 1983; Volume 10, pp. 1-30.

20. Cornell, D.H.; Pettersson, Å. Ion probe zircon dating of metasediments from the Areachap and Kakamas Terranes, Namaqua-Natal Province and the stratigraphic integrity of the Areachap Group. S. Afr. J. Geol. 2007, 110, 169-178. [CrossRef]

21. Cornell, D.H.; Humphreys, H.; Theart, H.F.J.; Scheepers, D.J. A collision-related pressure-temperature-time path for Prieska Copper Mine, Namaqua-Natal tectonic Province, South Africa. Precambr. Res. 1992, 59, 43-71. [CrossRef]

22. Cornell, D.H.; Pettersson, Å.; Simonsen, S.L. Zircon U-Pb emplacement and Nd-Hf crustal residence ages of the Straussburg granite and Friersdale Charnockite in the Namaqua-Natal Province, South Africa. S. Afr. J. Geol. 2012, 115, 465-484. [CrossRef]

23. Joubert, P. The Namaqualand Complex-a model of Proterozoic accretion? Trans. Geol. Soc. S. Afr. 1986, 89, 79-96.

24. Thomas, R.J.; von Veh, M.W.; McCourt, S. The tectonic evolution of southern Africa: An overview. J. Afr. Earth Sci. 1993, 16, 5-24. [CrossRef]

25. Van Bever Donker, J. Structural and Metamorphic Evolution of an Area around Kakamas and Keimoes, Cape Province, South Africa; Bulletin of the Precambrian Research Unit, University of Cape Town 28: Cape Town, South Africa, 1980; p. 165.

26. Van Bever Donker, J. The Neusspruit lineament, Upington geotraverse, possible boundary between the Namaqualand Metamorphic Complex and the Namaqua front. In Namaqualand Metamorphic Complex; Botha, B.J.V., Ed.; Special Publication of the Geological Society of South Africa: Johannesburg, South Africa, 1983; Volume 10, pp. 193-198.

27. Van Bever Donker, J. A synthesis of the structural geology of a major tectonic boundary between a $1000 \mathrm{~m} . \mathrm{y}$. mobile belt and a 3000 m.y. craton. Tectonophysics 1991, 196, 359-370. [CrossRef]

28. Colliston, W.P.; Praekelt, H.E.; Schoch, A.E. A progressive shear model for the Proterozoic Aggeneys Terrane, Namaqua mobile belt, South Africa. Precambr. Res. 1991, 49, 205-215. [CrossRef]

29. De Beer, J.H.; Meyer, R. Geoelectrical and gravitational characteristics of the Namaqua-Natal mobile belt and its boundaries. In Namaqualand Metamorphic Complex; Botha, B.J.V., Ed.; Special Publication of the Geological Society of South Africa: Johannesburg, South Africa, 1983; Volume 10, pp. 91-100.

30. De Beer, J.H.; Meyer, R. Geophysical characteristics of the Namaqua-Natal Belt and its boundaries. J. Geodynam. 1984, 1, 473-494. [CrossRef]

31. Madi, K. Seismicity and neotectonic uplift in the Augrabies Falls National Park, Namaqualand, Northern Cape, South Africa. Earthquake Sci. 2016, 29, 281-289. [CrossRef]

32. Eglington, B.M.; Armstrong, R.A. Geochronological and isotopic constraints on the Mesoproterozoic Namaqua-Natal Belt: Evidence from deep borehole intersections in South Africa. Precambr. Res. 2003, 125, 179-189. [CrossRef]

33. Eglington, B.M. Evolution of the Namaqua-Natal Belt, southern Africa-a geochronological and isotope geochemical review. J. Afr. Earth Sci. 2006, 46, 93-111. [CrossRef]

34. Armstrong, R.A.; de Wit, M.J. Armstrong, R.A.; de Wit, M.J. A summary of the geochronology and Precambrian crustal architecture of southern Africa, and possibilities for correlations with South America. In Problems in western Gondwana, Proceedings of South America-Africa correlations; Centro de Investigações do Gondwana: Gramado, Brazil, 2007; pp. 12-17.

35. Bailie, R.; Gutzmer, J.; Rajesh, H.M. Age of ferroan post-tectonic granitoids of the southern part of the Keimoes Suite, Northern Cape Province, South Africa. J. Afr. Earth Sci. 2011, 60, 153-174. [CrossRef] 
36. Bailie, R.; Rajesh, H.M.; Gutzmer, J. Bimodal volcanism at the western margin of the Kaapvaal Craton in the aftermath of collisional events during the Namaqua-Natal Orogeny: The Koras Group, South Africa. Precambr. Res. 2012, 200, $163-183$. [CrossRef]

37. Bailie, R.; Macey, P.H.; Nethenzheni, S.; Frei, D.; Le Roux, P. The Keimoes Suite redefined: The geochronological and geochemical characteristics of the ferroan granites of the eastern Namaqua Sector, Mesoproterozoic Namaqua-Natal Metamorphic Province, southern Africa. J. Afr. Earth Sci. 2017, 134, 737-765. [CrossRef]

38. Bial, J.; Büttner, S.H.; Frei, D. Formation and emplacement of two contrasting late-Mesoproterozoic magma types in the central Namaqua Metamorphic Complex (South Africa, Namibia): Evidence from Geochemistry and geochronology. Lithos 2015, 224, 272-294. [CrossRef]

39. Colliston, W.P.; Schoch, A.E. Tectonostratigraphic features along the Orange River in the western part of the Mesoproterozoic Namaqua mobile belt. S. Afr. J. Geol. 1998, 101, 91-100.

40. Colliston, W.P.; Schoch, A.E.; Praekelt, H.E. Stratigraphy of the Mesoproterozoic Aggeneys terrane, western Namaqua mobile belt, South Africa. S. Afr. J. Geol. 2012, 115, 449-464. [CrossRef]

41. Von Backström, J. The Geology of an Area around Keimoes, Cape Province, with Special Reference to Phacoliths of Charnockitic AdamellitePorphyry; Memoir of the Geological Survey of South Africa 53: Pretoria, South Africa, 1964; p. 218.

42. Pettersson, Å.; Cornell, D.H.; Moen, H.F.G.; Reddy, S.; Evans, D. Ion-probe dating of 1.2 Ga collision and crustal architecture in the Namaqua-Natal Province of southern Africa. Precambr. Res. 2007, 158, 79-92. [CrossRef]

43. Pettersson, Å. Mesoproterozoic Crustal Evolution in Southern Africa. Ph.D. Thesis, University of Gothenburg, Stockholm, Sweden, 2008

44. Slabbert, M.J.; Moen, H.F.G.; Agenbacht, A.L.D.; van der Merwe, S.W.; Siegfried, H.P. An. Introduction to the Proterozoic Rocks on the 1:250 000 Sheets 2820 Upington and 2920 Kenhardt. Pre-Summer Field School Guidebook; Geological Society of South Africa: Pretoria, South Africa, 1989; p. 90.

45. Waters, D. Metamorphic zonation and thermal history of pelitic gneisses from western Namaqualand, South Africa. Trans. Geol. Soc. S. Afr. 1986, 89, 97-102.

46. Waters, D.J. Thermal history and tectonic setting of the Namaqualand granulites, southern Africa: Clues to Proterozoic crustal development. In Granulites and Crustal Evolution; Vielzeuf, D., Vidal, P., Eds.; Kluver: Dondrecht, The Netherlands, 1990; pp. 243-256.

47. Sandiford, M.; Martin, M.; Zhou, S.; Fraser, G. Mechanical consequences of granite emplacement during high-T, low-P metamorphism and the region of "anti-clockwise" PT paths. Earth Planet. Sci. Lett. 1991, 107, 164-172. [CrossRef]

48. Bial, J.; Büttner, S.H.; Schenk, V.; Appel, P. The long-term high-temperature history of the central Namaqua Metamorphic Complex: Evidence for a Mesoproterozoic continental back-arc in southern Africa. Precambr. Res. 2015, 268, 243-278. [CrossRef]

49. Bial, J.; Büttner, S.; Appel, P. Timing and conditions of regional metamorphism and crustal shearing in the granulite facies basement of south Namibia: Implications for the crustal evolution of the Namaqualand metamorphic basement in the Mesoproterozoic. J. Afr. Earth Sci. 2016, 123, 145-176. [CrossRef]

50. Pederast, A.; von Backström, J.W. A study of an area at Kakamas. Trans. Geol. Soc. S. Afr. 1949, 52, 435-495.

51. Lipson, R. Lithogeochemistry and Origin of Metasediments Hosting the Broken Hill Deposit, Aggeneys, South Africa, and Implications for Ore Genesis. Ph.D. Thesis, University of Cape Town, Cape Town, South Africa, 1990.

52. McClung, C. Basin Analysis of the Mesoproterozoic Bushmanland Group of the Namaqua Metamorphic Province, South Africa. Ph.D. Thesis, University of Johannesburg, Johannesburg, South Africa, 2006.

53. Bailie, R.; Armstrong, R.; Reid, D. The Bushmanland Group supracrustal succession, Aggeneys, Bushmanland, South Africa: Provenance, age of deposition and metamorphism. S. Afr. J. Geol. 2007, 110, 59-86. [CrossRef]

54. Bailie, R.; Armstrong, R.; Reid, D. Composition and single zircon U-Pb emplacement and metamorphic ages of the Aggeneys Granite Suite, Bushmanland, South Africa. S. Afr. J. Geol. 2007, 110, 87-110. [CrossRef]

55. Theart, H. Copperton-Areachap Cu, Zn Mineralization. Ph.D. Thesis, University of Stellenbosch, Stellenbosch, South Africa, 1985.

56. Geringer, G.J.; Humphreys, H.C.; Scheepers, D.J. Lithostratigraphy, protolithology and tectonic setting of the Areachap Group along the eastern margin of the Namaqua mobile belt, South Africa. S. Afr. J. Geol. 1994, 97, 78-100.

57. Bailie, R.; Gutzmer, J.; Rajesh, H. Lithogeochemistry as a tracer of the tectonic setting, lateral integrity and mineralisation of a highly metamorphosed Mesoproterozoic volcanic arc sequence on the eastern margin of the Namaqua Province, South Africa. Lithos 2010, 119, 345-362. [CrossRef]

58. Diener, J. Low-P-high-T metamorphism of the Aggeneys terrane, Namaqua Metamorphic Complex, South Africa. S. Afr. J. Geol. 2014, 117, 31-44. [CrossRef]

59. Diener, J.F.A.; White, R.W.; Link, K.; Dreyer, T.S.; Moodley, A. Clockwise, low-P metamorphism of the Aus granulite terrain, southern Namibia, during the Mesoproterozoic Namaqua Orogeny. Precambr. Res. 2013, 224, 629-652. [CrossRef]

60. Stowe, C. The Upington Geotraverse and its implications for craton margin tectonics. In Namaqualand Metamorphic Complex; Botha, B.J.V., Ed.; Special Publication of the Geological Society of South Africa: Johannesburg, South Africa, 1983; Volume 10, pp. 147-171.

61. Humphreys, H.C.; van Bever Donker, J.M. Early Namaqua low-pressure metamorphism: Deformation and porphyroblast growth in the Zoovoorby staurolite schist, South Africa. J. Metam. Geol. 1990, 8, 159-170. [CrossRef] 
62. Stowe, C. Synthesis and interpretation of structures along the north-eastern boundary of the Namaqua Tectonic Province, South Africa. Trans. Geol. Soc. S. Afr. 1986, 89, 185-198.

63. Praekelt, H. Die geologie van die gebied rondom Augrabies (2820 C.). Master's Thesis, University of the Orange Free State, Bloemfontein, South Africa, 1984.

64. Büttner, S.H.; Fryer, L.; Lodge, J.; Diale, T.; Kazondunge, R.; Macey, P.M. Controls of host rock mineralogy and $\mathrm{H}_{2} \mathrm{O}$ content on the nature of pseudotachylyte melts: Evidence from Pan-African faulting in the foreland of the Gariep Belt, South Africa. Tectonophysics 2013, 608, 552-575. [CrossRef]

65. Moen, H. Petrology of the Wilgenhoutsdrif Group; Bulletin of the Geological Survey of South Africa 89: Pretoria, South Africa, 1988; p. 37.

66. Allmendinger, R.W.; Cardozo, N.C.; Fisher, D. Structural Geology Algorithms: Vectors and Tensors; Cambridge University Press: Cambridge, UK, 2013; p. 289.

67. Fleuty, M. The description of folds. Proceed. Geol. Assoc. 1964, 75, 461-492. [CrossRef]

68. Geringer, G. The Geology of the Archaean Rocks and Younger Formations in the Area to the West of Upington with Special Reference to Various Occurrences of Granite. Ph.D. Thesis, University of the Orange Free State, Bloemfontein, South Africa, 1973.

69. Thomas, R.J.; Macey, P.H.; Spencer, C.; Dhansay, T.; Diener, J.F.A.; Lambert, C.W.; Frei, D.; Nguno, A. The Sperrgebiet domain, Aurus Mountains, SW Namibia: A 2020-850 Ma window within the Pan-African Gariep orogen. Precambr. Res. 2016, 236, 35-58. [CrossRef]

70. Barton, E.S.; Burger, A.J. Reconnaissance isotopic investigations in the Namaqua mobile belt and implications for Proterozoic crustal evolution-Upington geotraverse. In Namaqualand Metamorphic Complex; Botha, B.J.V., Ed.; Special Publication of the Geological Society of South Africa: Johannesburg, South Africa, 1983; Volume 10, pp. 173-192.

71. Janney, P.E.; Shirey, S.B.; Carlson, R.W.; Pearson, D.G.; Bell, D.R.; Le Roex, A.P.; Ishikawa, A.; Nixon, P.H.; Boyd, F.R. Age, composition and thermal characteristics of South African off-craton mantle lithosphere: Evidence for a multi-stage history. $J$. Petrol. 2010, 51, 1849-1890. [CrossRef]

72. Pettersson, Å.; Cornell, D.H.; Yuhara, M.; Hirahara, Y. Sm-Nd data for granitoids across the Namaqua-Natal Province, South Africa. Geol. Soc. Lond. Spec. Publ. 2009, 323, 219-230. [CrossRef]

73. Ramsay, J. Shear zone geometry: A review. J. Struct. Geol. 1980, 2, 83-99. [CrossRef]

74. Ramsay, J.G.; Huber, M.I. The Techniques of Modern Structural Geology. Volume 1: Strain Analysis; Academic Press: London, UK, 1983; p. 307.

75. Stowe, C. Preliminary Report on Geodynamics in the Upington Geotraverse; Annual Report, Precambrian Research Unit, University of Cape Town: Cape Town, South Africa, 1980; Volume 24-48, p. 17.

76. Passchier, C.W.; Trouw, R.A.J. Microtectonics, 2nd ed.; Springer: Berlin, Germany, 2005; p. 371.

77. Passchier, C.W.; Coelho, S. An outline of shear-sense analysis in high-grade rocks. Gondwana Res. 2006, 10, 66-76. [CrossRef]

78. Oriolo, S.; Wemmer, K.; Oyhantcabal, P.; Fossen, H.; Schulz, B.; Siegesmund, S. Geochronology of shear zones-A review. Earth-Sci. Rev. 2018, 185, 665-683. [CrossRef]

79. Robin, P.Y.F.; Cruden, A.R. Strain and vorticity patterns in ideally ductile transpression zones. J. Struct. Geol. 1994, 16, 447-466. [CrossRef]

80. Passchier, C. Monoclinic model shear zones. J. Struct. Geol. 1998, 20, 1121-1137. [CrossRef]

81. Jacobs, J.; Thomas, R.J.; Weber, K. Accretion and indentation tectonics at the southern edge of the Kaapvaal craton during the Kibaran (Grenville) orogeny. Geology 1993, 21, 203-206. [CrossRef]

82. Clifford, T.N.; Barton, E.S.; Stern, R.A.; Duchesne, J.-C. U-Pb zircon calendar for Namaquan (Grenville) crustal events in the granulite-facies terrane of the O'okiep Copper District of South Africa. J. Petrol. 2004, 45, 669-691. [CrossRef] 